Portland State University

PDXScholar

1977

\title{
Purification and properties of lysozyme from Pseudomonas aeruginosa bacteriophage $7 \mathrm{v}$
}

Lynne Vernice McFarland

Portland State University

Follow this and additional works at: https://pdxscholar.library.pdx.edu/open_access_etds

Part of the Microbiology Commons

Let us know how access to this document benefits you.

\section{Recommended Citation}

McFarland, Lynne Vernice, "Purification and properties of lysozyme from Pseudomonas aeruginosa bacteriophage 7v" (1977). Dissertations and Theses. Paper 2987.

https://doi.org/10.15760/etd.2982

This Thesis is brought to you for free and open access. It has been accepted for inclusion in Dissertations and Theses by an authorized administrator of PDXScholar. Please contact us if we can make this document more accessible: pdxscholar@pdx.edu. 
AN ABSTRACT OF THE THESIS OF Iynne Vernice MCFarland for the Master of Science in Biology presented December 12, 1977. Title: Purification and Properties of Lysozyme from Pseudomonas aeruginosa Bacteriophage $7 \mathrm{v}$. APPROVED BY MEMBERS OF THE THESIS COMMITTEE:

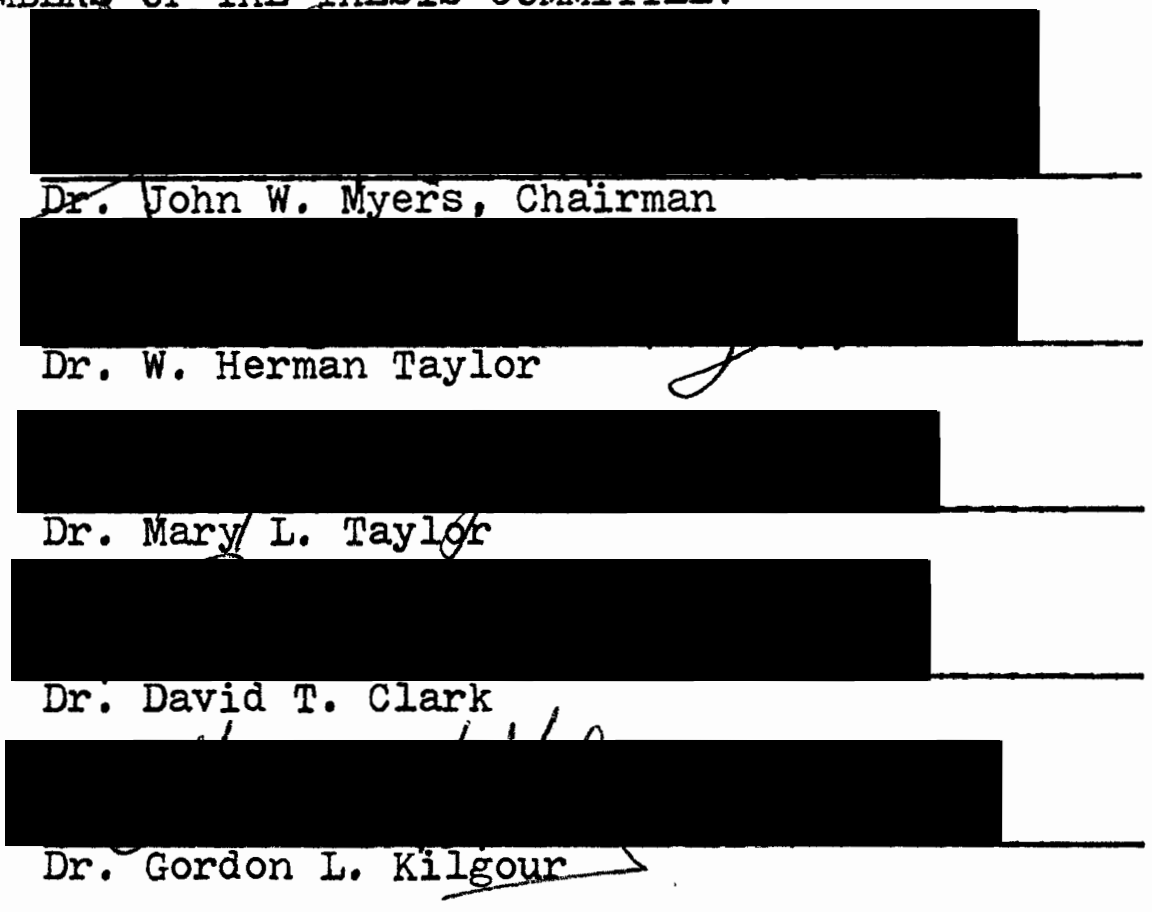

A lysozyme from Bacteriophage $7 \mathrm{v}$ was purified 7.7 fold over the original lysates of the bacteriophage $7 \mathrm{v}$ and Pseudomonas aeruginosa PS-7. This purification process includes ultracentrifugation, ammonium sulfate precipitation, dialysis, and fractionation in a sephadex G-150 column. The phage lysozyme exhibits a greater specificity when assayed with $\underline{P}$. aeruginosa cells as a substrate, but still is capable 
of acting on the standard lysozyme Micrococcus lysodeikticus substrate. The $\mathrm{pH}$ optimum, heat inactivation range, and action on other bacteria is described. The molecular weight was found to be 14,300 . The values of this $7 \mathrm{v}$ phage lysozyme are in close agreement with values found with other phage lysozymes. A possible treatment for burn wounds infected with Pseudomonas aeruginosa is also described. 
PURIFICATION AND PROPERTIES OF LYSOZYME FROM PSEUDOMONAS AERUGINOSA BACTERIOPHAGE TV

\section{by}

IYNNE VERNICE MCFARIAND

Lyme Vernice

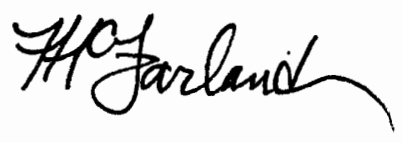

A thesis submitted in partial fulfillment of the requirements for the degree of

MASTER OF SCIENCE

in

BIOIOGY

Portland State University

1980 
TO THE OFFICE OF GRADUATE STUDIES AND RESEARCH:

The members of the Committee approve the thesis of Iynne Vernice McFarland Rresented December 12, 1977.

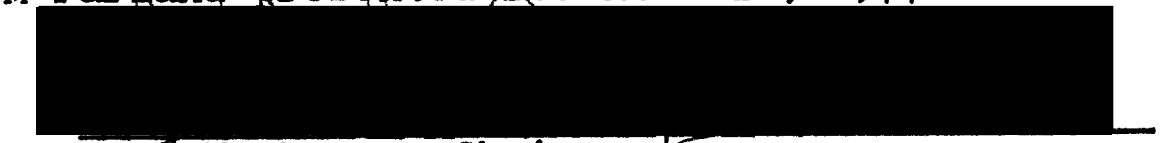

John W. Myers, Chairman

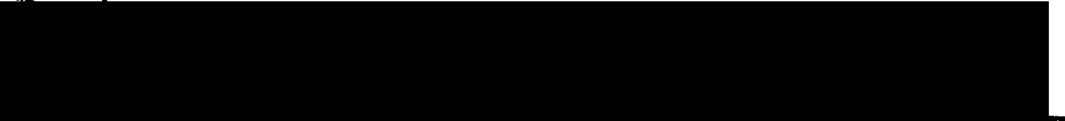

W. Herman Tay̆lor
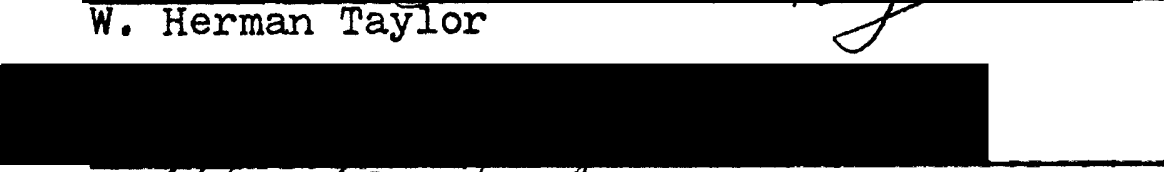

Mary' L. Taylor

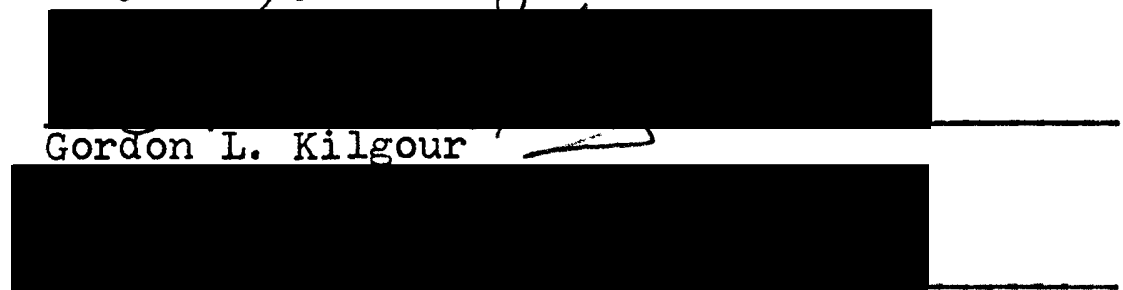

David T. Clark

\section{APPROVED:}

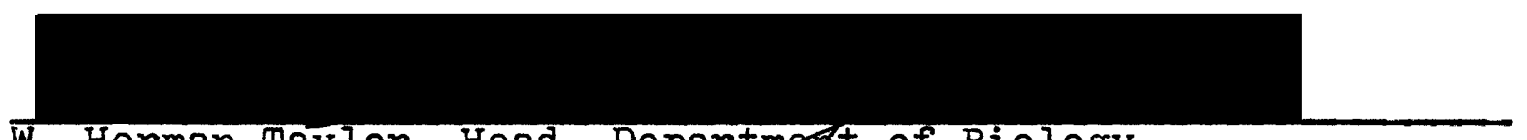

W. Herman Taylor, Head, Department of Biology

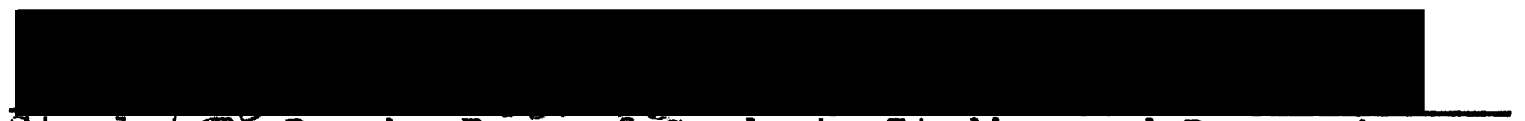

Stanley E. Rauch, Dean of Graduate Studies and Research 


\section{ACKNOWLEDGMENTS}

The author wishes to thank Dr. John W. Myers, Dr. W. Herman Taylor, and Dr. David T. Clark for their supportive guidance and interest during the course of this work.

The author is also grateful to Dr. Earl Fisher, Jr. for providing the bacterial and bacteriophage cultures and the early guidance he rendered.

The author is in special appreciation of Dr. Mary I. Taylor whose endless patience, enthusiasm, and technical assistance enabled this research to be successfully completed.

My thanks to Portland State University for financially assisting the author and other needy graduate students during their research.

The author has warm gratitude for her husband, Marcus J. McFarland, who gave her boundless support and had a great deal of patience through this study. 
TABLE OF CONTENTS

PAGE

ACKNOWLEDGMENTS . . . . . . . . . . . . . . iii

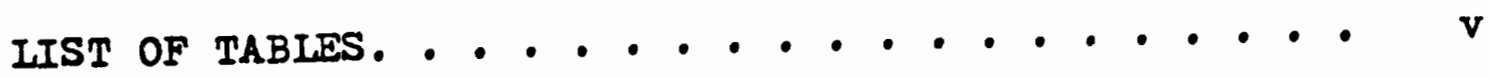

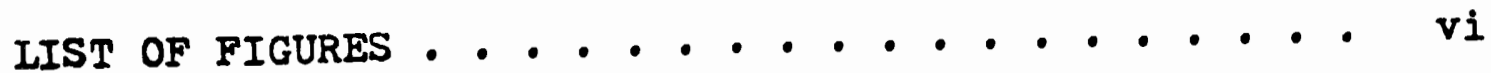

INTRODUCTION. . . . . . . . . . . . . . 1

MATERIAIS AND METHODS ... . . . . . . . . . 6

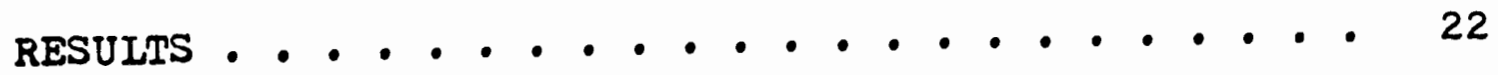
DISCUSSION AND COMPARISON WITH OTHER PHAGE IYSOZYMES. 50 CONCLUSIONS . . . . . . . . . . . . . 60 IITERATURE CITED. - . . . . . . . . . . 61 APPENDIX I. . . . . . . . . . . . . . 67 APPENDIX II . . . . . . . . . . . . . 68 


\section{LIST OF TABLES}

TABIE

PAGE

I Substrate Specificities . . . . . . . 16

II A Comparison of Plaque Count Assay on

Complete and Chemically Defined Media . 23

III Specific Activities of Lysate 1 and 2. . . 39

IV Results of the Purification Steps . . . . 40

V Standard Protein Values for Molecular Weight

Determination . . . . . . . 44

VI Phage 7v Lysozyme Action Against Other Bacteria. . . . . . . . . 49

VII PH Optima for Different Lysozymes . . . . . 56

VIII Molecular Weight Values of Lysozymes. . . . 57 


\section{IIST OF PIGURES}

FIGURE

PAGE

1. Site of Action of Iysozyme on Bacterial

Cell Walls . . . . . . . . . 2

2. Standard Growth Curve of P. eeruginosa PS-7. 10

3. Standard Protein Graph . . - . . . . 12

4. Enzyme Activity versus Enzyme Concentration. 14

5. Comparison of Iysozyme Activity and Protein

bands. . . . . . . . . . . 27

6. Percentage Ammonium Sulfate versus Enzyme

Activity in Precipitate/Input. . . - 28

7. Gel Filtration of Iysate 1 . . . . . - 32

8. Gel Filtration of Lysate 2 . . . . . 33

9. second Gel Filtration of Iysate 1. . . - 35

10. Second Gel Filtration of Iysate 2. . . . 36

11. Heat Inactivation of the Phage Iysozyme. - 42

12. Enzyme Lctivity versus $\mathrm{pH}$ in $0.1 \mathrm{M}$ Phosphate

Buffers. . . . . . . . . 43

13. Standard Molecular Weight Curve. . . . . 45

14. Action of Egg White and Phage Iysozyme on

the Same Substrate . . . . . . 47 


\section{INTRODUCTION}

Ever since the discovery of lysozyme by Sir Alexander Fleming in 1922, this enzyme has had a significant role in biological research (21). A clue to the importance of lysozyme can be seen by the fact that this enzyme is produced by a variety of organisms, viruses, plants, humans and other animals $(21,43,61)$. The fact that lysozyme is 80 widespread indicates that the enzyme must have an important function common to all these life forms. Iysozyme has been found to be lethal to bacterial cells but harmless to the eucaryotic cells which produce it (21). Iysozyme thus seems to play a part in the natural mechanism of resistance by the host against bacterial cell infections (43). When the importance in resistance to disease was established, lysozyme was further characterized.

Iysozyme is the common name for the en:yme known as mucopeptide N-acetylmuramy lhydrolase which attacks the $\beta(1-4)$ linkages between $N$-acetylmuramic acid and N-acetylglucosamine in the backbone of bacterial cell walls, as shown in Figure 1 (37). Iysozyme is thought to be effective in combatting bacterial infections from a wide range of bacterial genera. Iysozyme has been observed to act directly against most Gram positive bacterial cell walls, 

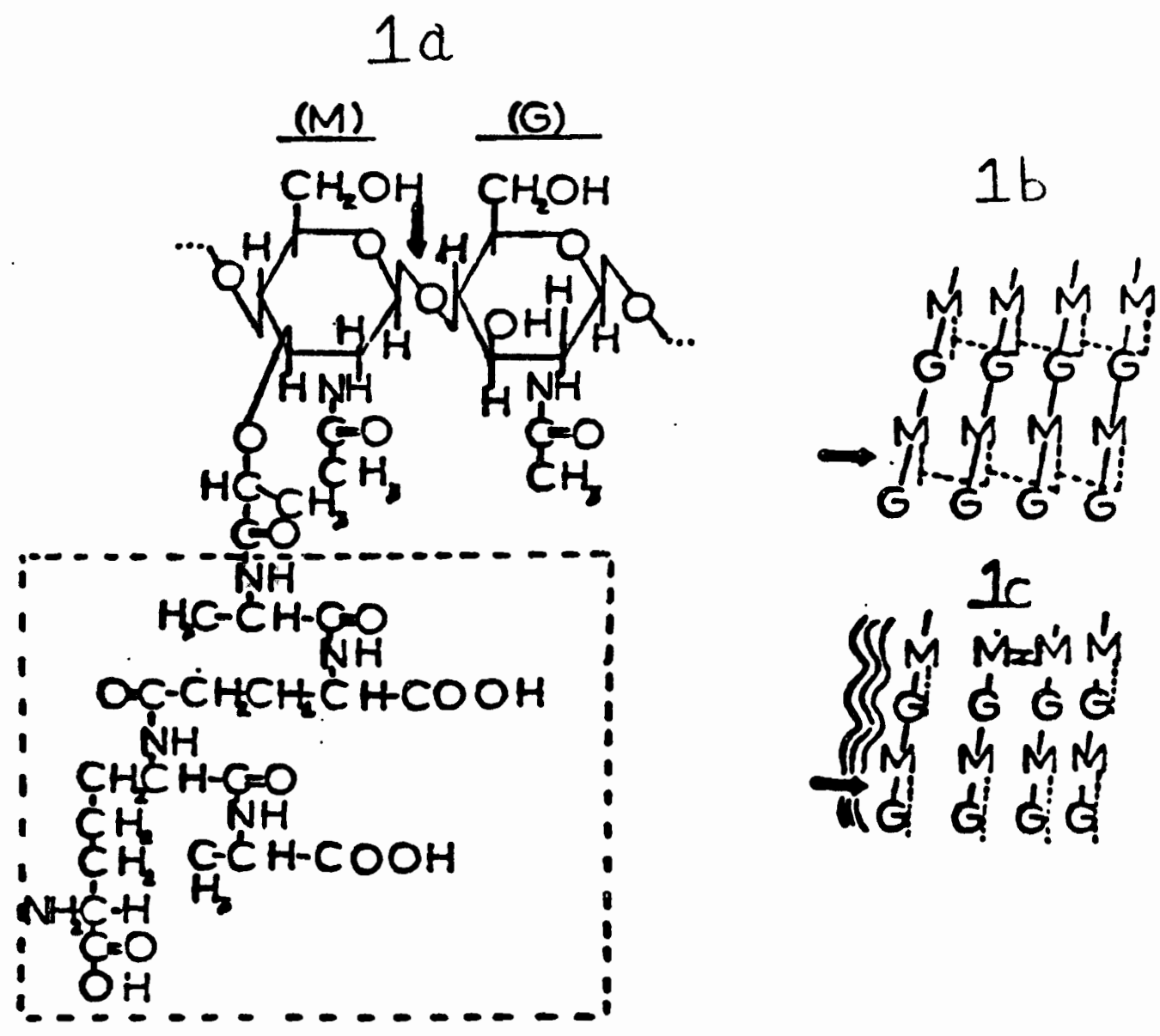

Figure 1. Site of action of lysozyme on bacterial cell walls. 1 a is a diagram of peptidoglycan (the primary unit of bacterial cell walis) showing the two subunits, N-acetylmuramic acid (M) with an associated polypeptide chain (in dashed box) and N-acetylglycosamine (G). The site of attack by lysozyme is shown by the arrow on all the diagrams. In Gram positive cells, $1 \mathrm{~b}$, a pentapeptide (horizontal dotted line) cross-links the tetrapeptides (vertical dotted line) of $\mathrm{N}$-acetylmuramic acid. In Gram negative cells, 1c, the tetrapeptides are linked directly. The wavy lines in $1 \mathrm{c}$ represent the lipoprotein and lipopolysaccharide layer present in Gram negative bacteria which acts as a barrier to lysozyme penetration. 
but Gram negative cells require pre-treatment to remove the protective lipopolysaccharide-lipoprotein layer before the lysozyme has direct access to its substrate $(48,55)$.

Although lysozymes from all sources share the ability to hydrolyze glycosidic $\beta(1-4)$ linkages between $N$-acetylmuramic acid and $\mathrm{N}$-acetylglycosamine, there are several classes of lysozymes depending on the hydrolytic activity on other substrates. In addition to the peptidoglycan layer of bacterial cell walls, some types of lysozyme also act on chitin, chitodextrins, and some fungi. $(6,43)$.

Iysozymes made by various organisms are all basic proteins of low molecular weight (from 13,000 to 24,000 ) with isoelectric points ranging from $\mathrm{pH} 10$ to 11 so that the enzymatic proteins maintain a net positive charge over most of the common $\mathrm{pH}$ ranges in aqueous media $(43,58)$. Lysozymes also have a native structure which withstands sharp changes in $\mathrm{pH}$, temperature, and salt concentrations showing a high degree of stability in most solutions (43). Bacteriophages, or viruses which attack bacterial cells, were also found to code for the production of lysozyme. This was first reported in Escherichia coli cells infected with T2 phage (33). Since then, several other phages have been found to produce lysozyme $(11,12,15,16,30$, $31,57,58)$. Iysozyme was found to be important in two periods of bacteriophage life cycles: penetration of the phage DNA into the bacterial cell $(8,23,31,33,55)$ and 
host cell lysis $(28,31,33,55)$. Early researchers thought that an identical lysozyme was responsible for both penetration of the viral genome and lysis of the host cell. Subsequent research with both E. coli phages $T 4$ and $T 7$ showed that the enzyme which was responsible for penetration and the enzyme responsible for host cell lysis had differing molecular weights $(17,52,55)$. This was the first indication that there existed more than one form of lysozyme. The discovery that the lysozyme responsible for the final lysis of the cell was coded for by a gene of the phage, not the bacterial cell, explained why different forms of lysozyme were found when the same strain of bacteria was attacked by different bacteriophage strains $(3,17,28,31,55,56)$.

Lysoryme isolated from a specific bacterium-bacteriophage system has been found to be effective against bacteria other than the original bacterial host species $(33,57,59)$. Hence the host range specificity of a bacteriophage is not a property of the phage lysozymes. Current research indicates some lysozymes may not be involved in the lysis of the bacterial cell. Silberstein et al. (52) has found the primary function of E. coli T? phage lysozyme to be the release of newly made T? DNA from the bacterial membrane with which it was associated. A lysozyme of $T$ is thus important in the phage assembly process and not the lysis of the bacterial cell. Silber- 
stein did point out that a lysozyme was needed to lyse the cell, but he did not characterize the one present in T7. Therefore, besides the lytic function, lysozyme may have additional functions that are not known or fully understood.

other current research on lysozyme includes the determination of its three dimensional structure $(16,24,47)$, the observation of the action of lysozyme on different substrates and binding sites $(27,40,47,50)$, the study of the enzyme as a serum factor and its interaction with pathogens $(39,63)$, and the use of lysozyme to determine bacterial cell wall composition $(43,48,59)$. The enzymatic specificities which vary depend on the infecting bacteriophage are being studied by several researchers $(11,50$, 52 ).

Pseudomonas aeruginosa is a bacterium important in secondary nosocomial (hospital-acquired) infections found in immunologically compromised patients, and is capable of causing corneal ulcers $(4,18,19,45,63)$. A DNA bacteriophage called $7 \mathrm{v}$ was discovered by Feary $(20)$ and is a virulent isolate unable to lysogenize the host Pseudomonas aeruginosa strain PS-7 (5). In preliminary work with this bacteriophage-host system, the presence of a lytic substance was noticed on agar plate cultures. This lytic substance, which appears to be a lysozyme, has been isolated and characterized in this study. 


\section{MATERIAIS AND METHODS}

Bacterial Culture

Pseudomonas aeruginosa strain PS-7 isolated from an ocular infection was provided by Dr. Earl Fisher, Jr. The stock culture was maintained by serial transfer on trypticase soy blood agar. The culture was grown on Difco nutrient broth supplemented with 0.3 per cent Difco yeast extract, $0.1 \mathrm{M} \mathrm{MgSO}_{4}, 0.1$ per cent $\mathrm{NH}_{4} \mathrm{NO}_{3}$, and 0.1 per cent sucrose (NBYEN). Agar plates were made by adding 1.5 per cent Difco agar to the liquid medium. Soft agar overlays were composed of Difco nutrient broth, $0.1 \mathrm{M} \mathrm{MgSO}_{4}$, with 1 per cent agar added. Synthetic minimal medium and Difco Casamino acid medium broth were also used when indicated and their compositions are Eiven in Appendix I.

Plates containing approximately $25 \mathrm{ml}$ of agar medium per plate were incubated at room temperature until all surface moisture had evaporated. Cultures of $\underline{P}$. aeruginosa $\mathrm{PS}-7$ were incubated at $37^{\circ} \mathrm{C}$.

\section{High-titer Lysates}

The need for a substantial amount of enzyme for purification purposes required the preparation of a lysate which had a high titer of phage. Twenty five milliliters (ml) of a 5-6 hour culture of $\underline{P}$. aeruginosa PS-7 was 
added to $500 \mathrm{ml}$ of NBYEN, in a 2000-ml flask, and incubated at $37^{\circ} \mathrm{C}$ without shaking until the culture was in late exponential phase and anaerobic respiration was noted by the production of Nitrogen gas bubbles in the broth. At this stage, the reading on a klett colorimeter with a 66 filter was approximately 150 and the bacterial concentration had reached $5 \times 10^{8}$ cells/ml as determined by a viable count. Readings taken from the Klett colorimeter were taken using the number 66 filter for all the remaining tests. Twenty $\mathrm{ml}$ of phage stock at a concentration of $1 \times 10^{10}$ phage $/ \mathrm{ml}$ were then added to $180 \mathrm{ml}$ of bacteria for an initial ratio of 2.2 phage per bacterial cell. The culture was allowed to incubate without shaking at $37^{\circ} \mathrm{C}$ for six hours and then was spun in a Sorvall Superspeed RC2L $-B$ centrifuge at $9,150 \times g$ for 20 minutes to remove cellular debris and unlysed bacterial cells. The pellet obtained by low speed preparation was discarded. Two similar batches of lysate were made with the same multiplicity of infection and using the identical procedure. The results obtained were two lysates, with one lysate containing three times the number of phages as the other lysate. The lysate with $1 \times 1011$ bacteriophage/ml was labelled Lysate 1 , and the lysate with $3.32 \times 10^{11}$ bacteriophage/ml was labelled Lysate 2 .

\section{Substrate Preparation}

P. aeruginosa PS-7 cells were grown in $500 \mathrm{ml}$ of NBYEN 
in a two liter flask, without shaking, at $37^{\circ} \mathrm{C}$ for 12 hours and were collected by centrifugation $(9,150 \times \mathrm{g}$ for 20 minutes) and resuspended in three $\mathrm{ml}$ of sterile distilled water. These bacterial cells were then added slowly to 30 $\mathrm{ml}$ of cold acetone $\left(-20^{\circ} \mathrm{C}\right)$ with stirring. Acetone was used instead of the usual ethylenediametetraacetic acid (EDTA) because EDTA, by Itself, causes $\underline{P}$. aeruginosa cells to lyse (55). Then the cells were filtered by suction using a Buchner funnel and whatman number 1 filter paper. The filter paper and cells were washed with cold ethyl alcohol $\left(-20^{\circ} \mathrm{C}\right)$. several times to remove excess acetone. The cells were air dried and stored in a desiccator. The final yield was 0.6 grams of dried cells/liter of culture in NBYEN. Other substrates used included: Micrococcus Iysodeikticus. supplied by Sigma Chemical Company as lyophilized cells; other Gram positive bacteria, lyophilized from broth cultures taken from Portland State University stock cultures, and other Gram negative bacteria prepared in the method for $\underline{\underline{P}}$. aeruginosa substrate, supplied from PSU stock cultures.

\section{Assay of $P$. aeruginosa $7 v$}

A sample of a 4-5 hour broth culture grown in NBYEN at $37^{\circ} \mathrm{C}$ with no active aeration was removed and an aliquot was placed immediately into an ice bath. The turbidity of the 
culture was determined using a klett colorimeter with a 66 filter. Samples of $0.1 \mathrm{ml}$ each of several serial dilutions of the aliquot in the ice bath were mixed with $3.0 \mathrm{ml}$ of soft agar overlay and poured immediately over. the surface of an agar plate. Three plates per dilution were made. The plates were then incubated for 24 hours at $37^{\circ} \mathrm{C}$. As shown on the standard growth curve on Figure 2, Klett readings and a viable cell count were correlated. Thereafter, the viable cell count was estimated by klett readings when the identical growth conditions were met and the growth of $\underline{p}$. aeruginosa was assumed to be in exponential phase.

\section{Assay of Bacteriophage 2v}

The presence of infective bacteriophage was detected by assaying for plaque-forming units (PFU) using a modified version of the soft agar overlay plaque count method described in Adams (1). From the lysate of a phage culture, a one $\mathrm{ml}$ aliquot was removed and placed in $8 \mathrm{ml}$ of NBYEN, along with $1 \mathrm{ml}$ of a $4-5$ hour culture of P. aeruginosa $\mathrm{PS}-7$. This preparation was allowed to incubate at $37^{\circ} \mathrm{C}$ for 10 minutes, which insured 99 per cent adsorption of the phage onto the bacterial cell wall (51). Then serial dilutions of this mixture were made and placed in an ice bath. To provide an adequate background lawn for the plaques, $1.0 \mathrm{ml}$ of an overnight culture of $\underline{P}$. aeruginosa $\mathrm{PS}-7$ was then added to each soft agar tube. 


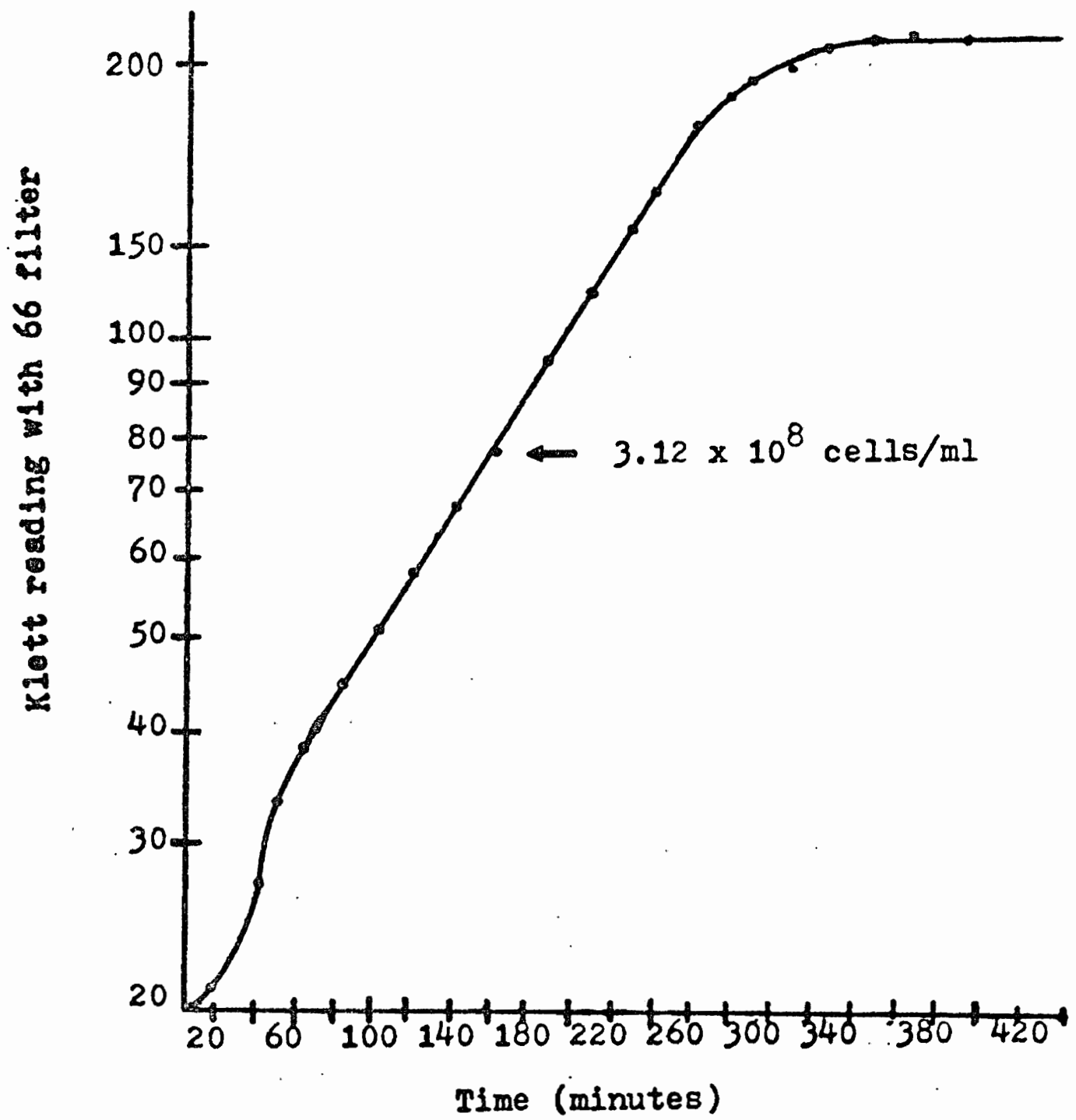

Figure 2. Standard growth curve of P. aeruginosa PS-7. P. aeruginosa PS-7 was grown in NBYEN at $37^{\circ} \mathrm{C}$ with no active aeration. 
A $0.1 \mathrm{ml}$ aliquot was removed from each dilution and added to three $\mathrm{ml}$ of soft agar overlay and poured immediately on top of an agar plate. Three plates per dilution were made. The plates were incubated for 24 hours at $37^{\circ} \mathrm{C}$ and then the plaques were counted; if no plaques were present, the plates were re-examined after another 24 hours incubation.

\section{Protein Determination}

The protein was determined by the procedure described by Lowry (36) with the exception that the copper sulfate and the potassium sodium tartrate solutions were kept separate until time of use. As seen in Figure 3, a standard graph of klett reading with a 66 filter versus Bovine serum albumin protein was made. At each step of the enzyme purification process, the sample was prepared as described by Lowry and the klett reading was taken. The amount of protein present in each fraction was determined by reading the amount of protein off the standard graph.

\section{Assay of Lysozyme Activity}

Two different procedures were used for the measurement of lysozyme activity.

Assay method 1. Using the procedure described in

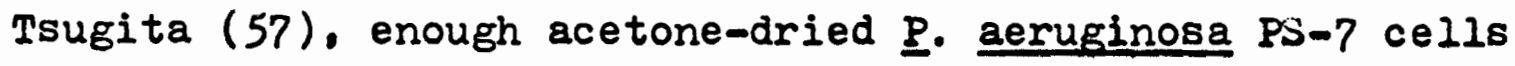
were suspended in three $\mathrm{ml}$ of $0.1 \mathrm{M}$ phosphate buffer to give 
12

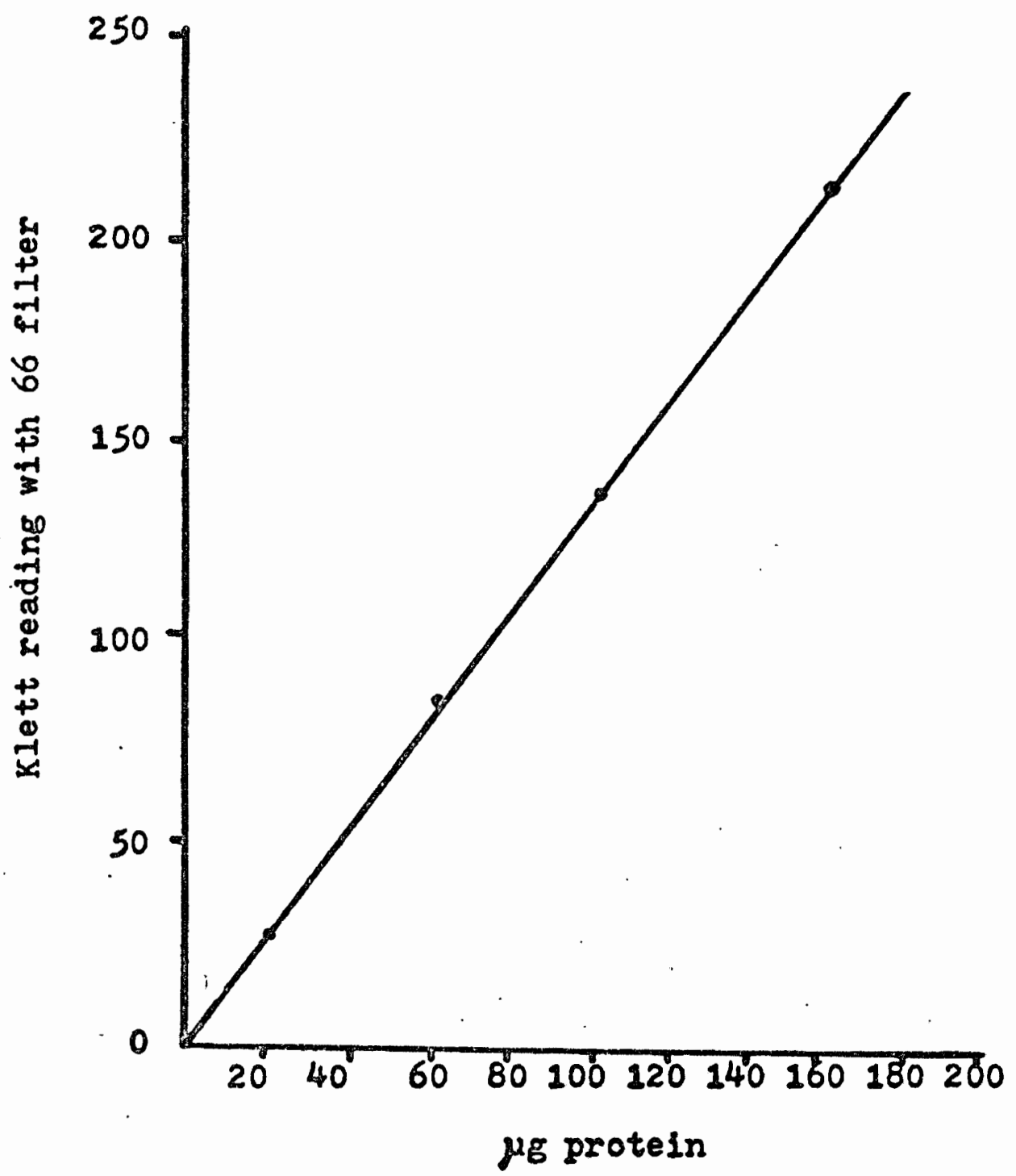

Pisure 3. Standard protein Eraph. 
an optical density reading in a Perkin-Elmer spectrophotometer of 0.6 at $660^{\circ} \mathrm{nm}$ wavelength. The assay was initiated by the addition of an enzyme sample and the time in minutes for the optical density reading to decrease by 0.1 was measured at room temperature.

To demonstrate this assay was valid, the reciprocal of the measured time in minutes was plotted against the concentration of the enzyme, as seen in Figure 4. Assay method 2. A more widely used measure of lysozyme activity is the standard lysozyme assay procedure which uses Micrococcus lysodeikticus as a substrate (65). This method was modified by substituting acetone-dried P. aeruginosa PS-7 cells for lyophilized M. lysodeikticus cells. $\underline{P}$. aeruginosa PS-7 cells were suspended at a concentration of $0.3 \mathrm{mg} / \mathrm{ml}$ in $0.1 \mathrm{M}$ phosphate buffer at $\mathrm{pH}$ 7.0. The reaction was initiated by the addition of a $0.1 \mathrm{ml}$ aliquot of the enzyme sample to $2.9 \mathrm{ml}$ of the substrate suspersion in a quartz cuvette with a one $\mathrm{cm}$ light pathway and was measured against a water blank. The decrease in absorbance was noted at 15 second intervals for two minutes. The graph of the change in optical density plotted against enzyme concentration was similar to Figure 4. One unit of enzyme activity was defined as the amount of protein which produces a decrease in optical density of 0.001 units per minute at a wavelength of $450 \mathrm{~nm}$, a temperature of $25^{\circ} \mathrm{C}$ and $\mathrm{pH}$ of 7.0 , measured. in a Perkin-Elmer spectrophotometer. 


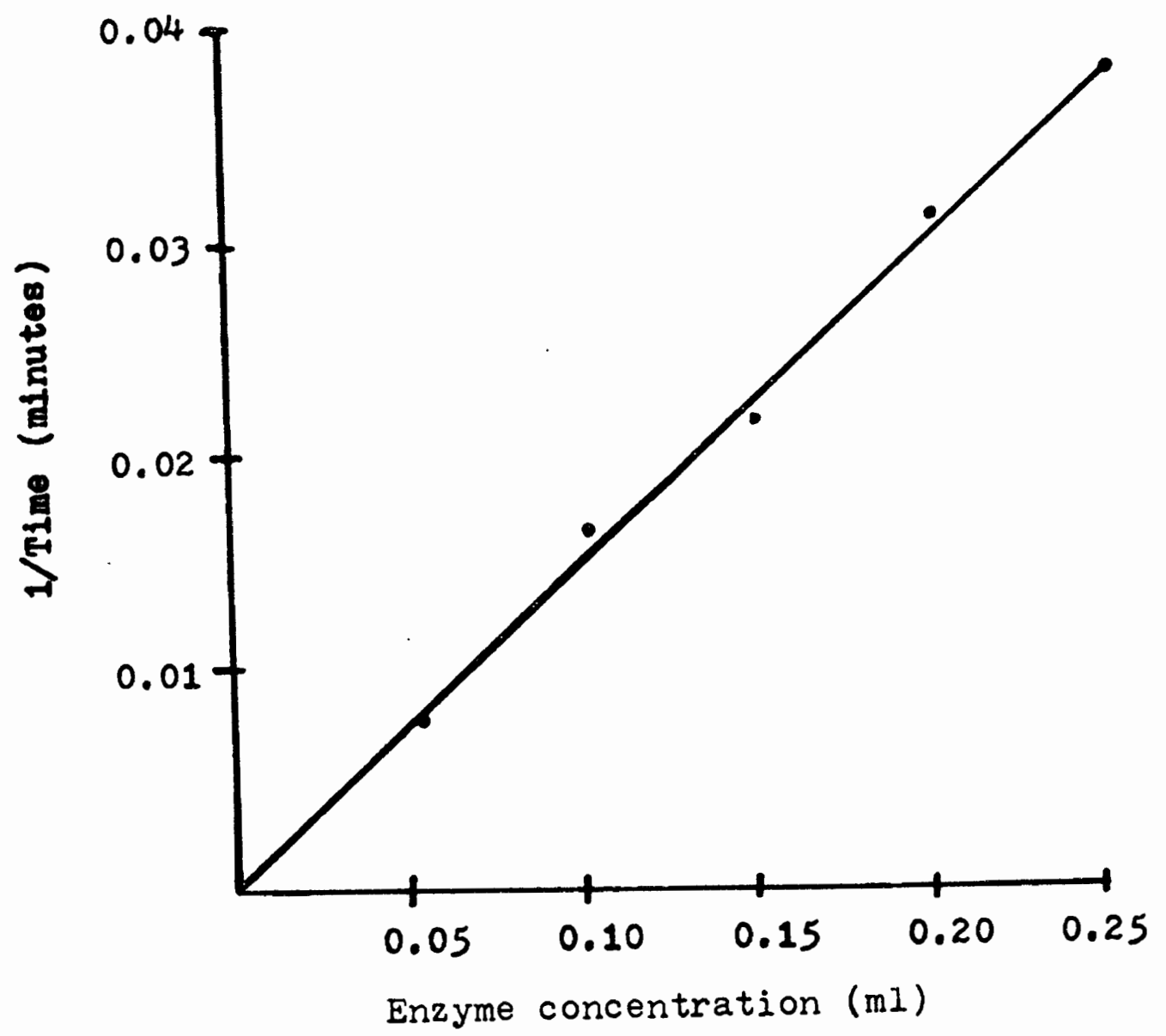

Pigure 4. Enzyme activity versus enzyme concentration. Activity was determined using assay method 1. 
The two substrates were initially compared to determine which substrate would be more sensitive to lysis by phage 7v lysozyme. M. Iysodeikticus cells and acetonedried $\underline{P}$. aeruginosa $\mathrm{P} \dot{-}-\mathrm{T}$ cells were assayed with standard egg white lysozyme and phage $7 \mathrm{v}$ enzyme. The concentration of the standard egg white lysozyme was 0.002 grams $/ 50 \mathrm{ml}$ distilled water. The source of the phage $7 \mathrm{v}$ lysozyme was the supernatant of crude lysate 2 . It was found that egg white lysozyme and phage $7 \mathrm{v}$ lysozyme both lyse P. aeruginosa $P S-7$ cells and $M$. lysodeikticus cells. As seen in Table $I$, the phage $7 \mathrm{v}$ lysozyme has a greater activity on the $\underline{\underline{p}}$. aeruginosa cell substrate. since the P. aeruginosa substrate was lysed more readily, P. aeruginosa PS-7 cells were used as the substrate instead of the M. Iysodeikticus substrate for the lysozyme assay.

\section{Chemicals And Reagents}

A list of the chemicals and companies that supplied them, along with the lot numbers are found in Appendix II. All chemicals and reagents were obtained commerially and were of reagent or analytical grade.

Ammonium Sulfate Precipitation

Using the procedures found in Green (25) and Williams (62). proteins were selectively precipitated by varying the percentage of ammonium sulfate which was added to the supernatants of ultracentrifuged lysates. 
TABIE I

SUBSTRATE SPECIFICITIES

M. Iysodeikticus cells and

$0.1 \mathrm{mI}$ standard egg white lysozyme $\left(4 \times 10^{-5}\right.$ grams $\left./ \mathrm{ml}\right)$

P. aeruginosa cells and and $0.1 \mathrm{ml}$ standard egg white lysozyme

(4 $\times 10-5$ grams $/ \mathrm{ml})$

M. Iysodeikticus cells and

$0.1 \mathrm{ml}$ phage $7 \mathrm{v}$ lysozyme from the supernatant of

crude Lysate 2

$P$. aeruginosa cells and 0.1 ml phage $7 \mathrm{v}$ Iysozyme from the supernatant of crude Lysate 2 
To determine which percentage of ammonium sulfate would precipitate out lysozyme, ten identical aliquots of ultracentrifuged Iysate 1 were made. Each aliquot was brought up to a certain percentage of ammonium sulfate, correcting for volume changes, and spun in a Sorvall centrifuge at $14,650 \times \mathrm{g}$ for 30 minutes. The precipitate was resuspended to its original volume in 0.1 M phosphate buffer at $\mathrm{pH} 7.0$. Iysozyme activity was measured by assay method 2 .

Dialysis

Dialysis was used to both remove contaminating materials and also to remove the ammonium sulfate salts and was done following the procedure found in Campbell (9). The material from the ammonium sulfate step, in a ten $\mathrm{ml}$ aliquot, was put inside dialysis tubing which was then sealed with a plastic clip at each end and placed in a beaker with $100 \mathrm{ml}$ of $0.1 \mathrm{M}$ phosphate buffer, $\mathrm{pH} 7.0$. Dialysis was carried out at $5^{\circ} \mathrm{C}$, with stirring, for 24 hours with the dialysate buffer being replaced every six hours. Ammonium sulfate was detected by adding two drops of Nessler reagent to a ten $\mathrm{ml}$ sample and observing for a yellow color.

Sephadex Gel Filtration

Fractionation was carried out following a modified procedure found in Reiland (46) and Green (25). Seventy grams of Sephadex G-150 Eel beads (10 to 40 mesh) were added to $200 \mathrm{ml}$ of $0.1 \mathrm{M}$ phosphate buffer, $\mathrm{pH} 7.0$, and 
allowed to swell at $90^{\circ} \mathrm{C}$ for one hour. After overnight cooling, the gel was poured into a $2.5 \times 38 \mathrm{~cm}$ column and equilibrated for one hour by washing it with $0.1 \mathrm{M}$ phosphate buffer, $\mathrm{pH} 7.0$, and $0.1 \mathrm{MKCl}$, at a flow rate of $0.106 \mathrm{ml} / \mathrm{minute.} \mathrm{A} \mathrm{three} \mathrm{ml}$ sample was added to the top of the column and eluted by washing with $0.1 \mathrm{M}$ phosphate buffer, $\mathrm{pH} 7.0$, at a flow rate of $0.106 \mathrm{mI} / \mathrm{minute.}$ Fractions were collected in $1.7 \mathrm{ml}$ aliquots and the protein was estimated by optical density readings at $280 \mathrm{~nm}$ and also by a Lowry determination. Iysozyme activity was determined for each fraction using assay. method 2 .

Blue dextran 2000 was always added to mark the void volume and was collected and read at $600 \mathrm{~nm}$. Care had to be taken to achieve the same void volume in each trial or else volume corrections would have been necessary. Blue dextran was applied to the top of the column along with the sample and $1.7 \mathrm{ml}$ fractions were collected. The blue dextran 2000 was measured by reading optical density at $600 \mathrm{~nm}$. The volume eluted to the fraction of maximum color was the void volume.

\section{Polyacrylamide Gel Electrophoresis}

Gel electrophoresis was carried out according to the procedure of Davis and others $(11,22,64)$. A current of 1.25 milliamps per tube was applied from the time the sample travelled through the seven per cent stacking gel until the stacked disc reached the resolving gel, which 
took thirty to sixty minutes. Once the discs entered the resolving gel, a current of 2.5 milliamps per tube was applied until the leading sample front marked by one per cent Bromophenol blue tracer dye reached approximately two $\mathrm{cm}$ from the bottom, whereupon the electrophoresis was terminated. This resolution step took approximately one to two hours. Half of the gels were stained with Coomassie blue following the procedure found in Chrambach (10). The gels were then stored in 7.5 per cent acetic acid in the dark to prevent the dye from fading. The position of the lysozyme was detected by slicing the unstained gels into two $\mathrm{ml}$ segments using a gel-slicer fabricated by the Portland State University Science shop. Each gel segment was incubated with $2.9 \mathrm{ml}$ of the $\underline{p}$. aeruginosa $\mathrm{PS}-7$ substrate for 30 minutes to allow protein diffusion out of the gel. The gel fractions were assayed for lysozyme activity by assay method 2 .

\section{Comparison of Enzyme Specificity}

P. aeruginosa substrate $(0.00235 \mathrm{~g})$ was dissolved in three $\mathrm{ml}$ of $0.1 \mathrm{M}$ phosphate buffer, $\mathrm{pH} 7.0$. Two $\mathrm{mg}$ of standard egg white lysozyme was added to initiate the reaction and the optical density was followed at $450 \mathrm{~nm}$ and recorded at ten minute intervals. When the optical density readings levelled off, either more standard egg white lysozyme (two $\mathrm{mg}$ ) was added or pahge $7 \mathrm{v}$ lysozyme $(0.1 \mathrm{ml}$ of Lysate 2$)$ was added and the results noted. 
Heat Inactivation

Three $\mathrm{ml}$ of the ultracentrifuged lysate 2 was incubated for five minutes at one of the temperatures ranging from $30^{\circ} \mathrm{C}$ to $75^{\circ} \mathrm{C}$ in a $1.5 \times 10 \mathrm{~cm}$ test tube in a hot water bath and then plunged immediately into an ice bath to cool. The residual activity was then measured using assay method 2 .

\section{PH Optimum}

P. aeruginosa PS-7 substrate $(0.00235$ grams ) was dissolved in three $\mathrm{ml}$ volumes of $0.1 \mathrm{M}$ phosphate buffer of different $\mathrm{pH}$ values. The reaction was initiated by the addition of $0.2 \mathrm{ml}$ of ultracentrifuged enzyme and assayed by assay metinod 1 .

\section{Molecular Weight Determination}

Dissimilar proteins are eluted from a sephadex column in different fractions according to size and molecular weight. The molecular weight was determined by the jephadex Cel Filtration method described by Andrews and others (2, 13.31). Two proteins of known but dissimilar molecular weights (two $\mathrm{mg}$ each) were mixed in five $\mathrm{ml}$ of 0.1 phosphate buffer, $\mathrm{pH} 7.0$, ten per cent sucrose and one per cent Blue dextran 2000 and applied to a Sephadex G-150 column. As previously described, $1.7 \mathrm{ml}$ fractions were collected and assayed for protein by optical density readings at $280 \mathrm{~nm}$. This sequence was repeated for another pair of 
proteins of known molecular weight. The elution volume was noted for each known protein and plotted on a graph as log molecular weight versus elution volume. A straight line was obtained. Then the protein of unknown molecular weight was applied to the column in the same buffer as that of the known proteins and the elution volume noted. The elution volume was plotted on the calibration curve of the known proteins and the molecular weight was read off. The void volume was determined for each filtration using Blue dextran 2000 as described previously. 


\section{RESUUTS}

\section{Enzyme Purification}

In most cases where an enzyme is to be isolated from bacterial growth, a medium is selected which is not rich in other proteins. As shown in Table I, the phage yield was very low on minimal or casamino acid medium. Schnider (51) found that growth in minimal medium resulted in less phage yield per cell than growth in a NBYE broth. She could not demonstrate the specific cofactor, or cofactors, that was required for phage absorption. She found the bacteria were not undernourished in the minimal medium, but some unknown cofactor or cofactors existed in NBYE which helped in phage adsorption. In order to get a high production of phage so that an adequate amount of enzyme could be isolated from the system, a rich medium had to be used. The results using the different media showed that a rich medium, NBYEN, gave the highest titer, as seen in Table II, and because of this fact NBYEN was the medium used throughout this study.

\section{Initial lysates of $\underline{P}$. aeruginosa $P S-7$ and the} bacteriophage $7 \mathrm{v}$ contained lytic activity in the fluid supernatant of the lysate. A purification procedure was needed so that the lytic substance could be isolated and characterized. Tsugita (33) and Koch (57) described 
TABLE II

\section{A COMPARISON OF PLAQUE \\ ASSAY ON COMPLETE AND \\ CHEMICALIY DEFINED \\ MEDIA}

Growth Mediuma

Plaque-forming units $/ \mathrm{ml}$

Minimal Medium

broth

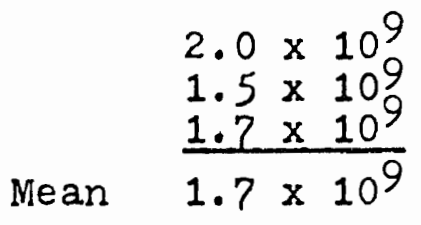

Casamino Acid

broth

Mean $\begin{array}{r}5.0 \times 10^{9} \\ 4.0 \times 10^{9} \\ 3.0 \times 10^{9} \\ \hline .0 \times 10^{9}\end{array}$

NBYEN

$2.8 \times 10^{11}$

broth

\begin{tabular}{l}
$2.8 \times 10^{11}$ \\
$3.0 \times 10^{11}$ \\
$3.2 \times 10^{11}$ \\
\hline Mean $3.0 \times 10^{11}$
\end{tabular}

aP. aeruginosa PS-7 cells were grown in the three types of growth media; NBYEN, Casamino Acid and Minimal Medium, until the bacterial concentration reached approximately $10^{8}$ bacteria/ml. Bacteriophage $7 \mathrm{v}$ was then added at a ratio of two phage per bacterial cell and the mixture was incubated for six hours at $37^{\circ} \mathrm{C}$. Triplicate plaque assays were made on agar medium of the same composition to determine the number of plaque-forming units per $\mathrm{ml}$ in each type of medium at the end of the incubation period. 
purification procedures for E. coli phage lysozymes and these two methods were used as a basis for $\underline{P}$. aeruginosa phage $7 \mathrm{v}$ lysozyme purification.

In order to determine if the lytic enzyme was produced by bacterium-bacteriophage interaction or was an enzyme produced by the bacterium alone, $\underline{P}$. aeruginosa PS-7 cells were prepared using the same method for lysate preparation, with the exception that no bacteriophage were added. The broth culture of $\underline{P}$. aeruginosa $\mathrm{Ps}-7$ was centrifuged at $9,150 \times \mathrm{g}$ for 20 minutes and assayed for lysozyme production. Centrifuged preparations of uninfected $\underline{P}$. aeruginosa PS-7 cells did not exhibit lysozyme activity in the supernatant or the pellet. The presence of the bacteriophage was needed to obtain Iysozyme activity.

The cell free lysates were prepared as described in the Materials and Methods section. After low speed centrifugation the lysate supernatant still contained plaqueforming units (PFU) and enzymatic activity and the pellet had neither enzymatic activity nor PFU. Lysozyme activity was measured using assay method 2. Lysate 1 had 25 units/m 1 and Iysate 2 contained 70 units/ml.

Lysate 2 , which had three times as much phage as Iysate 1, had approximately three times as much enzymatic activity, and this pattern was present in the remaining purification steps.

In order to observe if enzymatic activity was 
associated with the phage particle, the lysates were spun In Beckman Model I2-65B Ultracentrifuge at $28,000 \times \mathrm{g}$ for 2.5 hours. The majority ( 99.9 per cent) of the PFU were found in the pellet, in contrast, 92 per cent of the lysozyme activity was in the supernatant and only eight per cent of the lysozyme activity was found associated with the PFU in the pellet. Since Lysate 2 had three times as many PFU, as well as approximately three times as much enzymatic activity, the possibility that the presence of increased enzyme activity was associated with PFU was eliminated by centrifugation.

Recovery of lysozyme activity was 90 . per cent for Lysate 1 and 88 per cent for Iysate 2. The enzyme was purified 1.2 fold for Iysate 1 and 1.3 fold for Iysate 2 over the original lysate, as determined by specific activity ratios. This step had no significant effect on enzyme recovery.

In order to see how many contaminating proteins were still associated with the enzyme, a polyacrylamide gel electrophoresis was done as described in Materials and Methods on the ultracentrifuged supernatants of Iysate 1 and Iysate 2. Two gels were made of each lysate so that one could be stained for protein bands and one gel, left unstained, could be assayed for lysozyme activity. The results of the electrophoresis ohowed that there were more than ten bands of protein and each lysate showed 
similar protein band patterns.

In order to locate the protein with lysozyme activity. the unstained gel of each lysate was cut into two $\mathrm{mm}$ plugs and an assay was done on each plug as described in Materials and Methods using assay method 2. As shown in Figure 5, a drop in adsorbance occurred at $28 \mathrm{~mm}$ corresponding to the single protein band associated with lysozyme activity, with a $R_{f}$ value of 0.606 . $R_{f}$ represents the ratio of the distance the protein migrated in the resolving gel over the distance migrated by the buffer dye front in the same resolving gel.

Ammonium sulfate precipitation has been used as a method of separating proteins of different compositions. This procedure works because different proteins are precipitated out at different concentrations of the salt. In general, as the ammonium sulfate salt concentration is increased, proteins tend to become less soluble and come out of the solution.

Samples of Lysate 1 were precipitated by various strengths of ammonium sulfate (from 10 to 80 per cent) and the concentration which precipitated out the most enzyme was used to treat the remaining lysate. As seen in Figure 6, 70 per cent saturated solutions of this salt precipitated most of the enzyme. Thus, samples of both Lysate 1 and 2 were concentrated with this concentration of ammonium sulfate salt. 


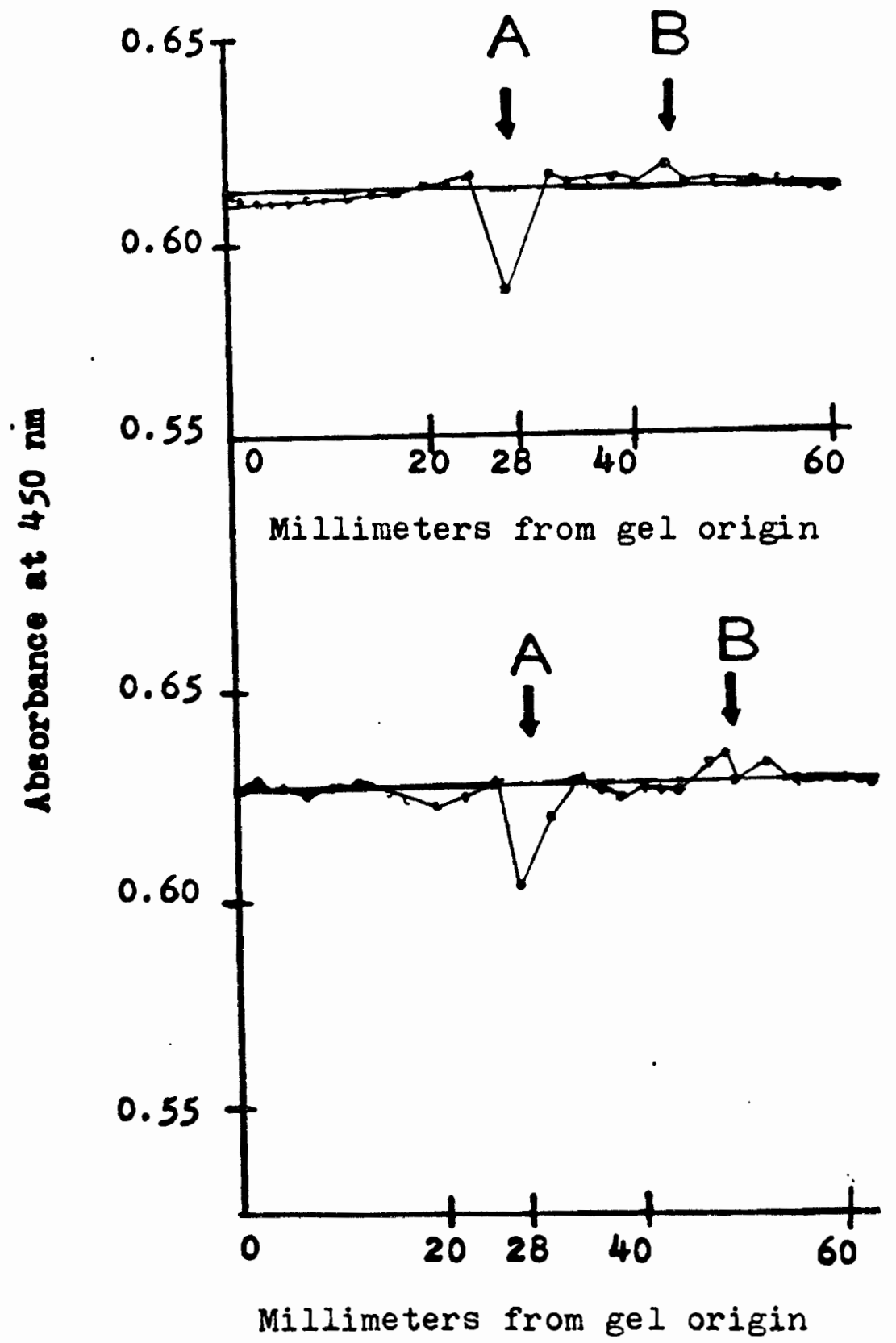

Figure 5. Comparison of lysozyme activity and protein bands. Each figure is a plot of absorbance readings versus millimeters from the gel origin. The top

figure is of Lysate 1 , and the bottom is of Lysate 2 . A drop in absorbance (A) indicates the substrate has been acted upon by the protein band seen at $28 \mathrm{~mm}$ in the electrophoresis disc. The tracking dye is $B$. 


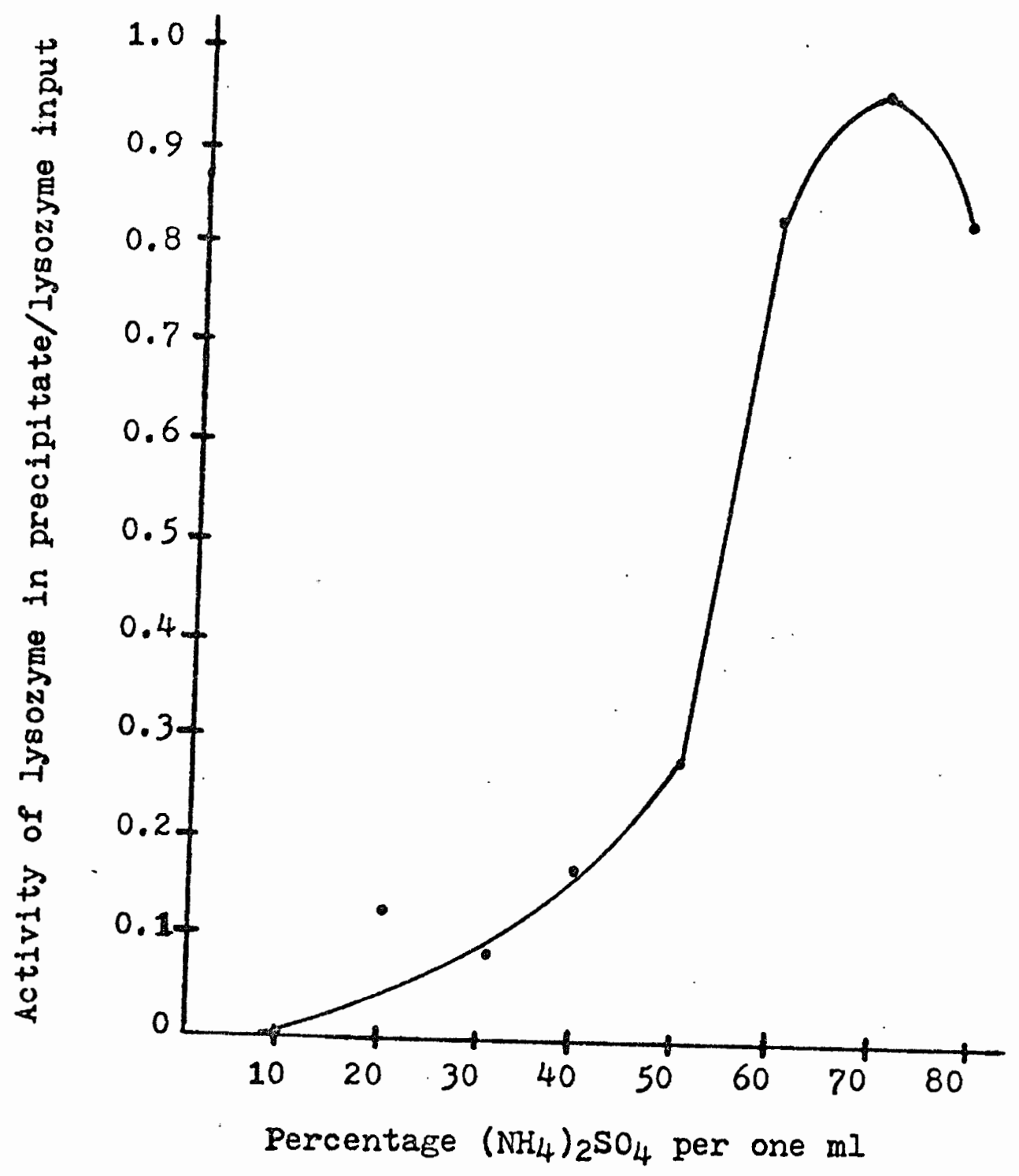

Figure 6. Percentage Ammonium sulfate versus enzyme activity in precipitate/enzyme input. In eight aliquots of Iysate 1 ammonium sulfate was added to make concentrations of 10-80 per cent. The supernatant and precipitate of the spun ammonium sulfate treated lysate were tested for lysozyme activity by assay method 2 . 
Recovery of lysozyme activity for Lysate 1 was 82 per cent and 83 per cent for Lysate 2. The enzyme was purified 3.0 fold for Lysate 1 and 2.2 fold for Lysate 2. No PFU were detected in the precipitate.

Ammonium sulfate was removed by dialysis against 0.1 M phosphate buffer, $\mathrm{pH} 7.0$, at $5^{\circ} \mathrm{C}$ for 24 hours so the salt would not interfere with the remaining purification steps. After dialysis, the enzyme, along with an average of 42 per cent of non-active proteins was found inside the dialysis tubing and the ammonium sulfate was found outside the tubing in the dialysate. Enzyme activity was detected by assay method 2; protein was determined by absorbance at $280 \mathrm{~nm}$, along with a Lowry determination; and ammonium sulfate presence was detected using Nessler's reagent which turns yellow in the presence of ammonium ions.

After dialysis, there was a lysozyme recovery of 59 per cent for Iysate 1 and 56 per cent for Iysate 2 . The enzyme was purified 4.4 fold for Lysate 1 and 2.4 fold for Lysate 2 .

Gel filtration through a Sephadex G-150 column was used as a means of purification because this process can be used to separate materials according to the molecular weight and size without inactivating the proteins. A sample of dialyzed ammonium sulfate treated lysate was introduced to the top of a column of the porous gel beads. The larger molecules were prevented, because of their 
bulk, from entering the pores of the gel beads and passed unhindered through the column and arrived at the bottom before the smaller proteins. The smaller proteins entered the pores and thus it took the proteins longer to pass through all the pores in the gel beads before leaving the column. By assaying for both the presence of protein and lysozyme activity, it was possible to separate out the protein peak that contained the phage $7 \mathrm{v}$ enzyme. Preliminary work showed the Sephadex G-150 gel size gave the best resolution of the different protein peaks. Columns of $G-15, G-25$ and $G-100$ resulted in a single broad band with little separation between the differing proteins.

Blue dextran 2000 was used as the visible marker of the void volume and because of the high molecular weight of this dye, $2 \times 10^{6}$ daltons, the dye was completely excluded from the gel pores and passed unhindered through the column. The void volume for all filtrations through Sephadex G-150 columns remained at a constant $60 \mathrm{ml}$. Any protein sufficiently small to enter the pores of the beads would require more than $60 \mathrm{ml}$ and the exit of the small proteins would be determined by their molecular weights. The relative rates of elution of proteins are defined by $\mathrm{Ve} / \mathrm{Vo}$, which is the elution volume of the protein over the void volume. Each protein has a characteristic Ve/Vo. The columns were eluted with $0.1 \mathrm{M}$ phosphate buffer, $\mathrm{pH} 7.0$, and $1.7 \mathrm{ml}$ fractions which were eluted from the 
column were collected. The absorbance of each fraction was read at either $600 \mathrm{~nm}$ for the presence of the Blue dextran tracer dye or at $280 \mathrm{~nm}$ for the presence of protein. Each consecutive set of three fractions were then pooled and tested for lysozyme activity by assay method 2 and tested for protein by the Lowry method.

As seen in Figure 7, for Iysate 1, there were three absorbance peaks and lysozyme activity was found to be confined to the middle peak. Lysate 2 was also fractionated by the Sephadex G-150 column and showed similar results, as shown in Figure 8 , except the absorbance peaks were three times as great as Lysate 1, as expected.

Lysozyme recovery for Lysate 1 was 26.4 per cent and for Lysate 2 was 28.4 per cent. The enzyme was purified 2.4 fold for lysate 1 and 2.1 fold for lysate 2 .

The separation of the proteins by one gel filtration did not result in the complete separation of the enzyme and the contaminating proteins. In order to isolate the enzyme in one peak free from other proteins, a second filtration using Sephadex $\mathrm{G}-150$ was done. Five $\mathrm{mI}$ samples of dialyzed ammonium sulfate treated lysates were fractionated through a Sephadex G-150 column. Protein peaks and void volume were determined by absorbance at $280 \mathrm{~nm}$ and $600 \mathrm{~nm}$, respectively. The lysozyme activity was determined. earlier to be in the middle peak of protein, so these fractions under the middle peak were pooled and fractionated 


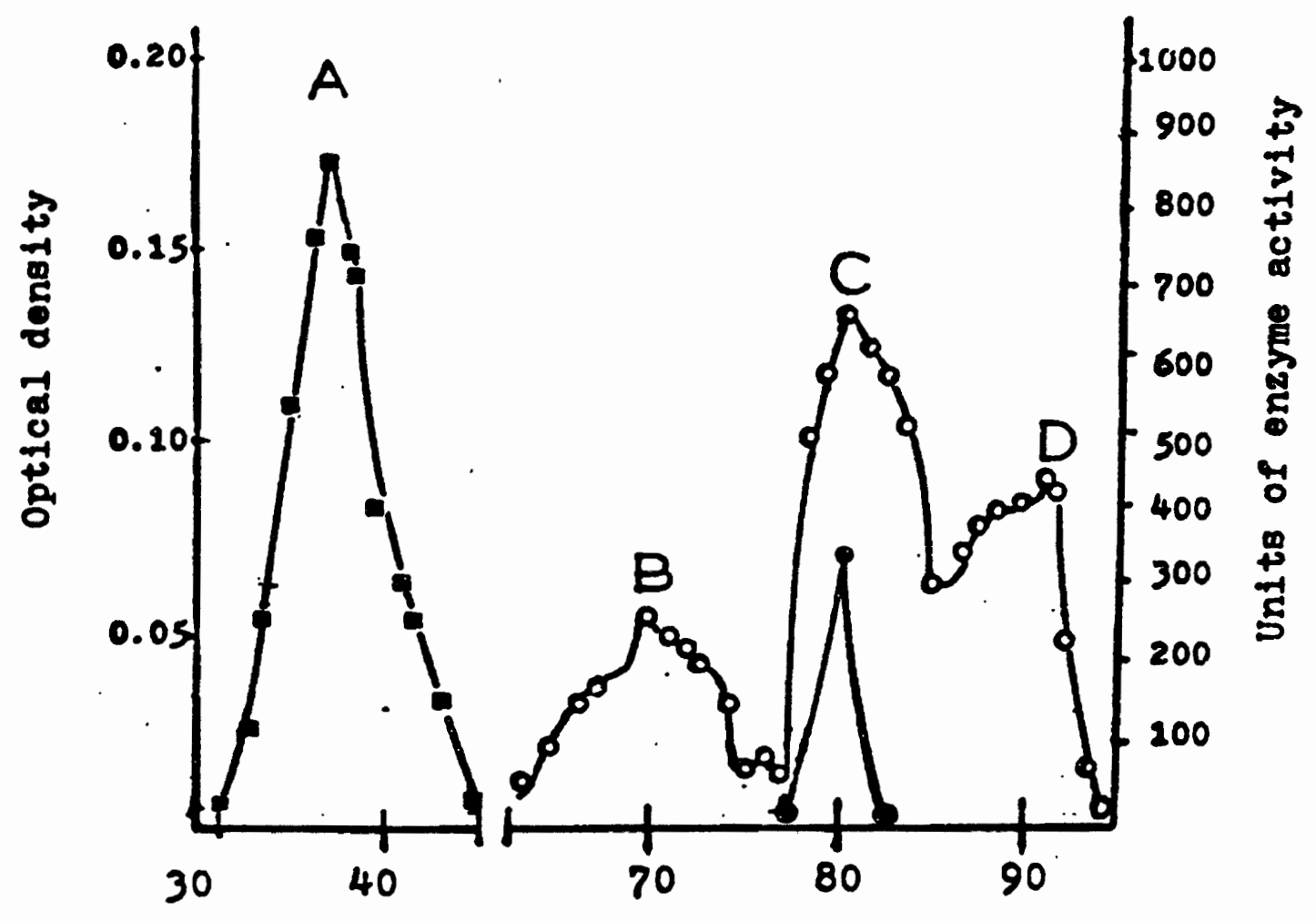

Tube number

Figure 2. First gel filtration of Lysate 1. Symbols: (a) optical density read at $600 \mathrm{~nm},(0)$ optical density read at $280 \mathrm{~nm}$; ( ) lysozyme activity. Peak A was the Blue dextran 2000 tracer dye. The void volume was $60.0 \mathrm{ml}$. Peak $\mathrm{C}$ was maximal at $134 \mathrm{ml}$ and the Ve/Vo equaled 2.23. Each tube contained $1.7 \mathrm{ml}$. Only peak $\mathrm{C}$ showed any lysozyme activity. Peaks $B$ and $D$ are contaminating proteins. 


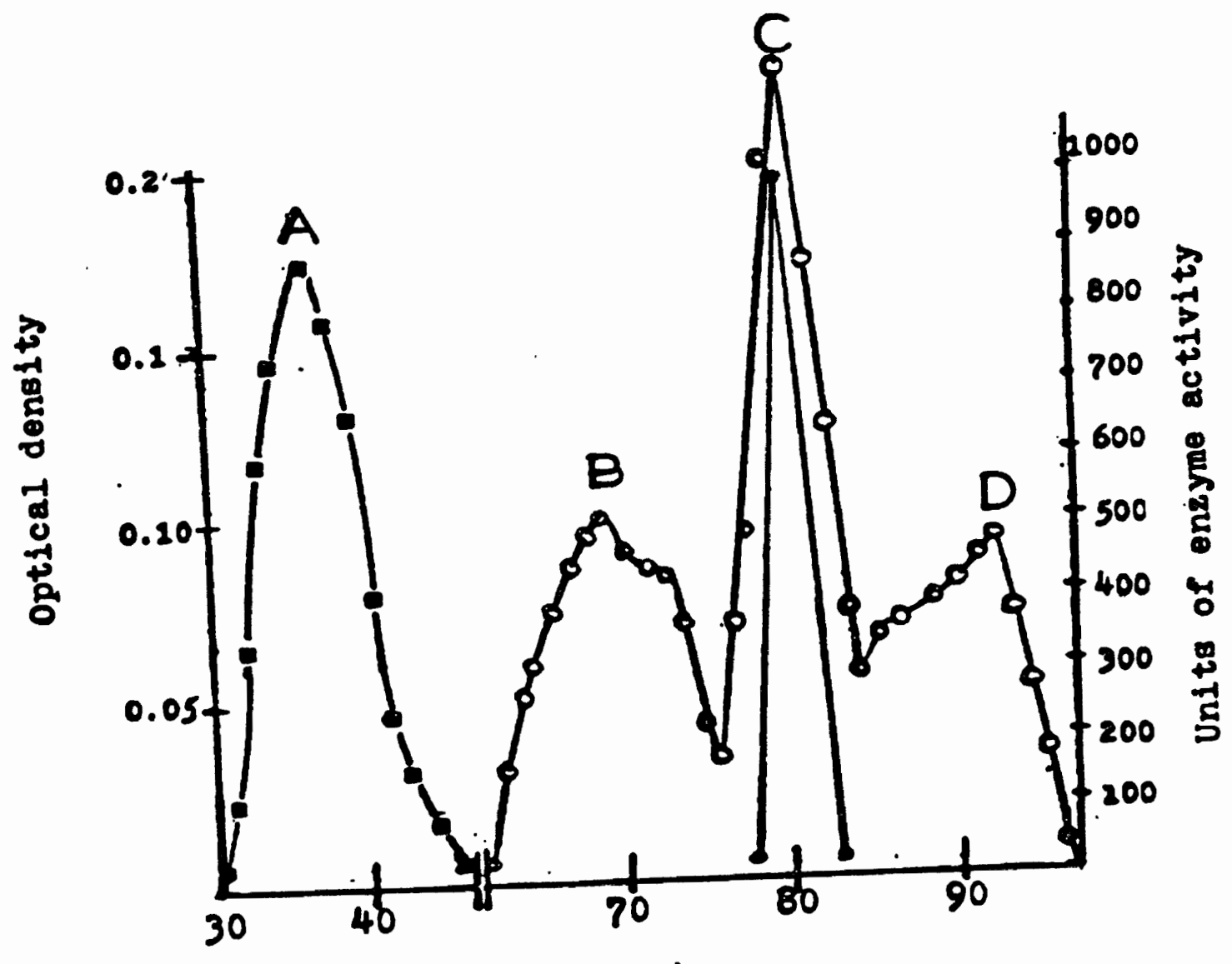

Tube number

Figure 8. First Eel filtration of Lysate 2. Symbols: (m) optical density read at $600 \mathrm{~nm}$ : ( 0 ) optical density read at $280 \mathrm{~nm}$ ( ) lysozyme activity. Peak $A$ was the Blue dextran 2000 tracer dye. $134 \mathrm{ml}$ and volume was $60.0 \mathrm{ml}$. Peak $\mathrm{C}$ was maximal contained $1.7 \mathrm{ml}$. the $\mathrm{Ve} / \mathrm{Vo}$ equaled 2.23. Each tube cons activity. Peaks $\mathrm{B}$ and $D$ are contaminating proteins. 
again on a Scphadex G-150 column. The fractionation of the pooled active fractions from the first Sephadex G-150 column was called the second gel filtration. The results of the second fractionation through the Sephadex G-150 are seen in Figure 9 for Iysate 1 and Figure 10 for Lysate 2. There was one major peak of absorbance with lysozyme activity and a small peak of non-active protein contaminants.

The final product was the three pooled fractions under the active peak and had an activity of 5.2 units $/ \mathrm{ml}$ for Lysate 1 and 16.1 units/ml for Lysate 2. The final recovery of lysozyme activity was 11 per cent for Lysate 1 and 12 per cent for Lysate 2. The enzyme was purified 7.5 fold for Lysate 1 and 7.7 fold for Lysate 2 . The specific activity of the pooled fractions was 30 for Lysate 1 and 108 for Lysate 2.

Since Sephadex gel filtration may result in a given fraction containing different proteins with identical molecular size, a polyacrylamide gel electrophoresis was done. Electrophoresis has the advantage of separating proteins according to not only the molecular weight, but also by the charge on the protein. Electrophoresis offered an additional method of proving that the one peak obtained by the second gel filtration contained one protein and not several similar proteins of identical molecular weights. A sample of dialyzed Lysate 2 was 


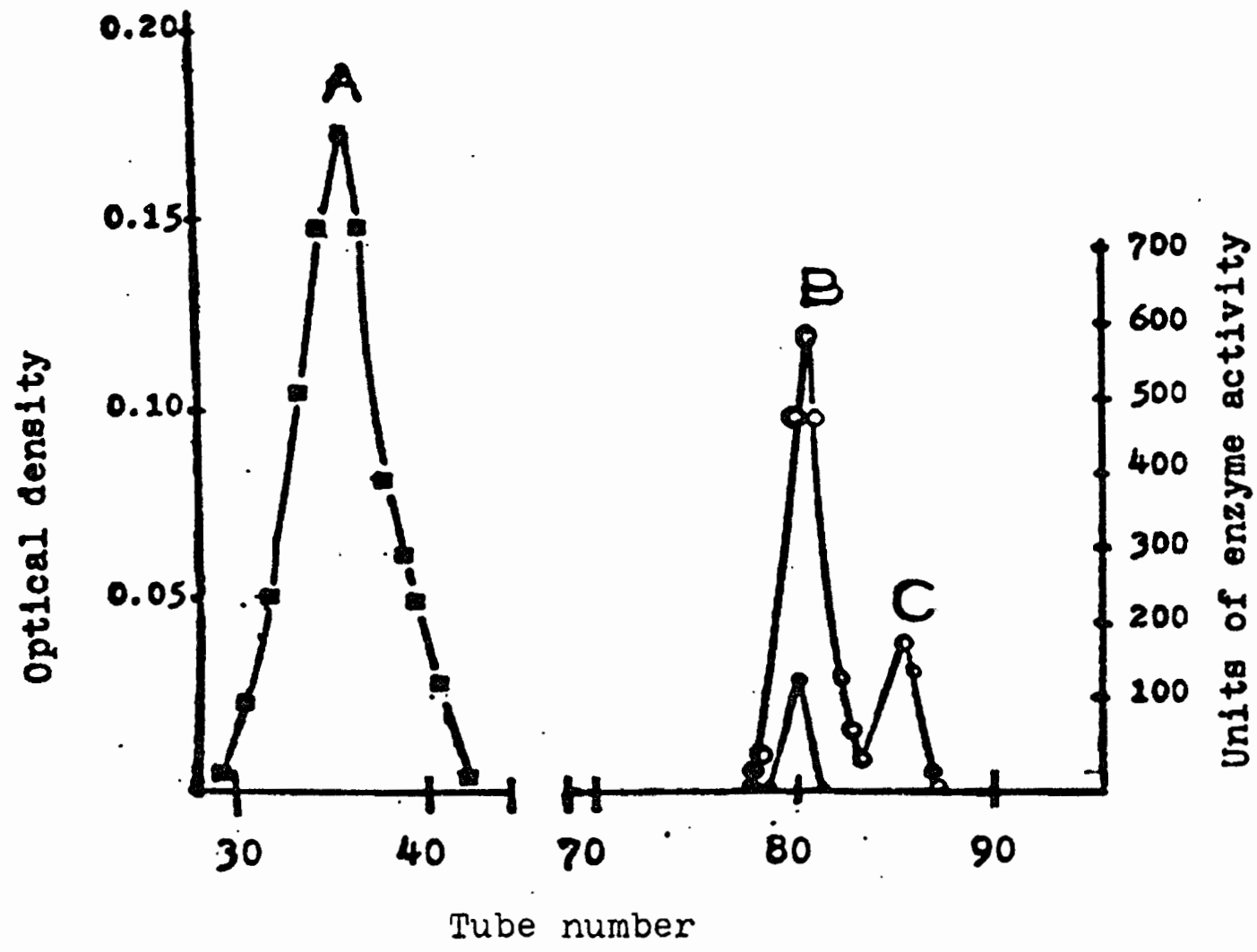

Figure 2. Second gel filtration of Lysate 1. Symbols: (G) optical density read at $600 \mathrm{~nm} ;(0)$ optical density read at $280 \mathrm{~nm}$; (o) lysozyme activity. Peak A was the Blue dextran 2000 tracer dye. The void volume was $60.0 \mathrm{ml}$. Peak $B$ was maximal at $134 \mathrm{ml}$ and the Ve/Vo equaled 2.23. Each tube contained $1.7 \mathrm{ml}$. Only peak B showed any lysozyme activity. Peak $\mathrm{C}$ was contaminating protein. 


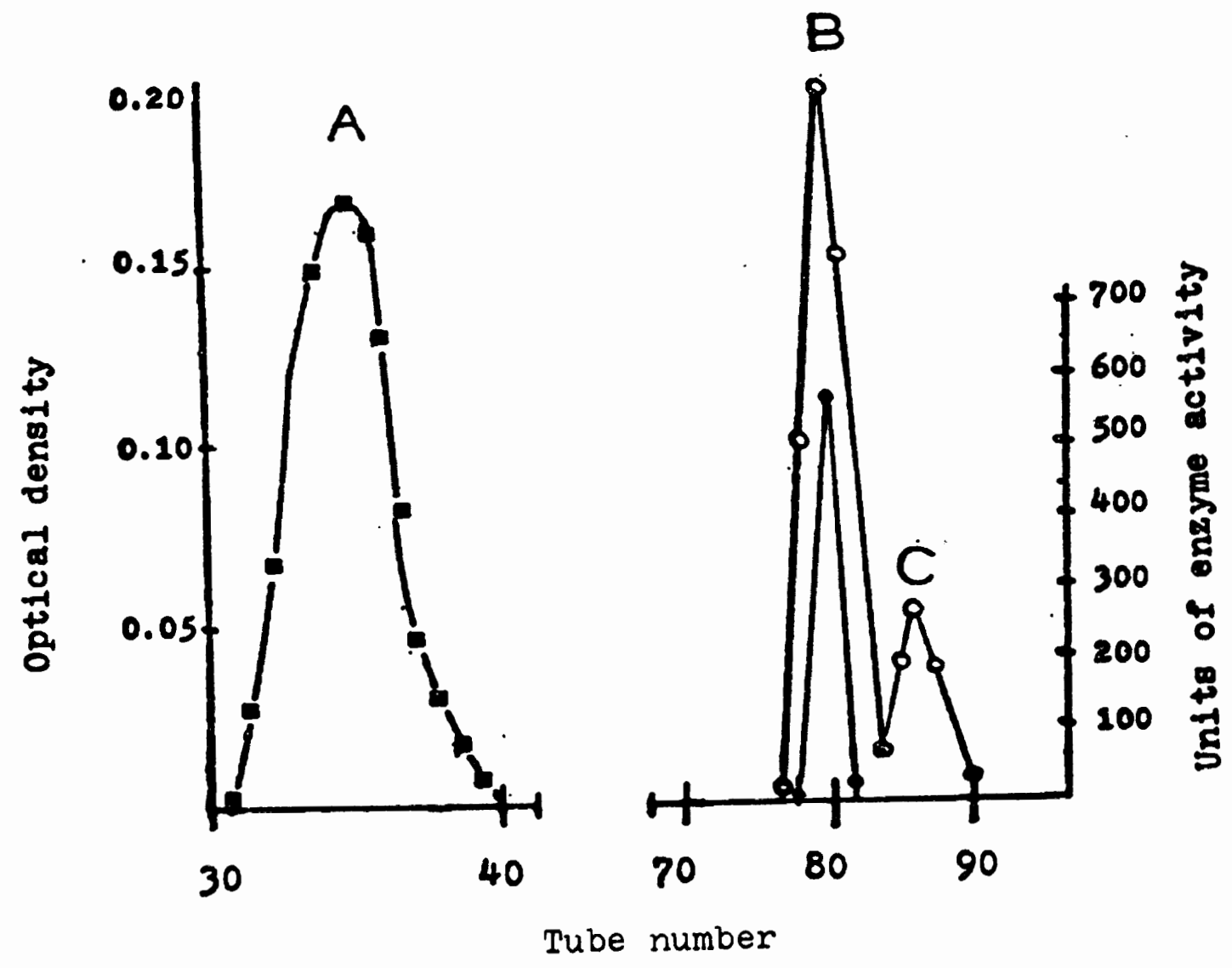

Figure 10. Second gel filtration of Lysate 2 . Symbols: (a) optical density read at $600 \mathrm{~nm}$; ( 0 ) optical density read at $280 \mathrm{~nm}$; ( $\bullet$ ) lysozyme activity. Peak A was the Blue dextran 2000 tracer dye. The void volume was $60.0 \mathrm{ml}$. Peak $B$ was maximal at $134 \mathrm{mI}$ and the Ve/Vo equaled 2.23. Each tube contained $1.7 \mathrm{ml}$. Only peak $\mathrm{B}$ showed any lysozyme activity. Peak $\dot{C}$ was contaminating protein. 
fractionated twice in Sephadex G-150 following the procedures described in Materials and Methods with one exception. The fractions were not pooled in threes after the second gel filtration, but left in $1.7 \mathrm{ml}$ fractions, assayed separately, and then pooled by threes and assayed again as pooled fractions. Absorbance at $600 \mathrm{~nm}$ and $280 \mathrm{~nm}$ were read for each fraction, protein was also determined by the Iowry method, and lysozyme activity was detected by assay method 2. The single fraction which had the highest absorbance reading of the unpooled fractions in the active peak was added to $0.4 \mathrm{ml}$ of Bromophenol blue and 40 per cent sucrose. Two ml samples were applied to two polyacrylamide gels. Electrophoresis was done following the procedure in Materials and Methods. One gel was stained for protein and one gel was sliced and assayed for lysozyme activity. The result of the polyacrylamide gel electrophoresis on the unpooled fraction of highest activity and absorbance was one band of protein with an $R_{f}$ value of 0.606 . Lysozyme activity obtained from the unstained gel was detected by assaying the gel plug corresponding to the protein band. The specific activity of the fraction of highest absorbance was 286.5. This final electrophoresis was not done with Iysate 1, as none was available.

Specific activity is indicative on the degree of enzyme purity. If the enzyme peaks in Figures 9 and 10 
are pure then different fractions under the same peak should have the same specific activity. If the specific activity derived from the same peak varies, then this indicates the enzyme is not completely pure.

The specific activity of the Sephadex G-150 filtration peaks of Lysate 1 and 2 were computed and compared. As seen from Table III, the specific activities of fractions under the same peak of lysate 1 and 2 differ. Iysate 1 has more contaminating protein or denatured non-active enzyme since that fraction's ratio is less than half than Iysate 2 's specific activities. The source of the contaminating protein in Lysate 1 was undetermined. Iysate 2 also showed varied specific activities from various fractions under the active peak. Although the result of gel electrophoresis of the single fraction of highest absorbance at $280 \mathrm{~nm}$ showed one band, the comparison of specific activities of different fractions under the active peak varies, showing the electrophoresis did not resolve the lysozyme from the contaminants.

A summary of the purification process and the resultant activities and protein levels are given in Table IV.

Characterization of The Enzyme

Heat Inactivation. All enzymes are susceptible to heat denaturation, but the range of heat inactivation has been observed to vary with the enzyme. As seen in Figure 
TABIE III

SPECIFIC ACTIVITIES OF IYSATE 1 AND 2

FRACTION

HIGHEST FRACTION FRACTION POOLED

PEAK $^{a}$ BEFORE AFIER ${ }^{C}$ FRACTION

Second Gel Filtration

of Lysate 1

133.3

$75.0 \quad 30.0$

30.6

Second Gel Filtration of Iysate 2

286.0

149.0

64.5108 .0

Gel electrophoresis. of

Second Gel Filtration 286.5 of Iysate 2

$147.0 \quad 66.7$ e

aThe peak referred to is the peak which high protein and lysozyme activity was detected. Refer to Peak $B$ in Figures 9 and 10.

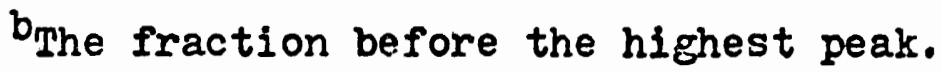

The fraction after the highest peak.

dPooled fraction consists of the highest peak fractions, and the fractions before and after.

eThese fractions were not pooled. 


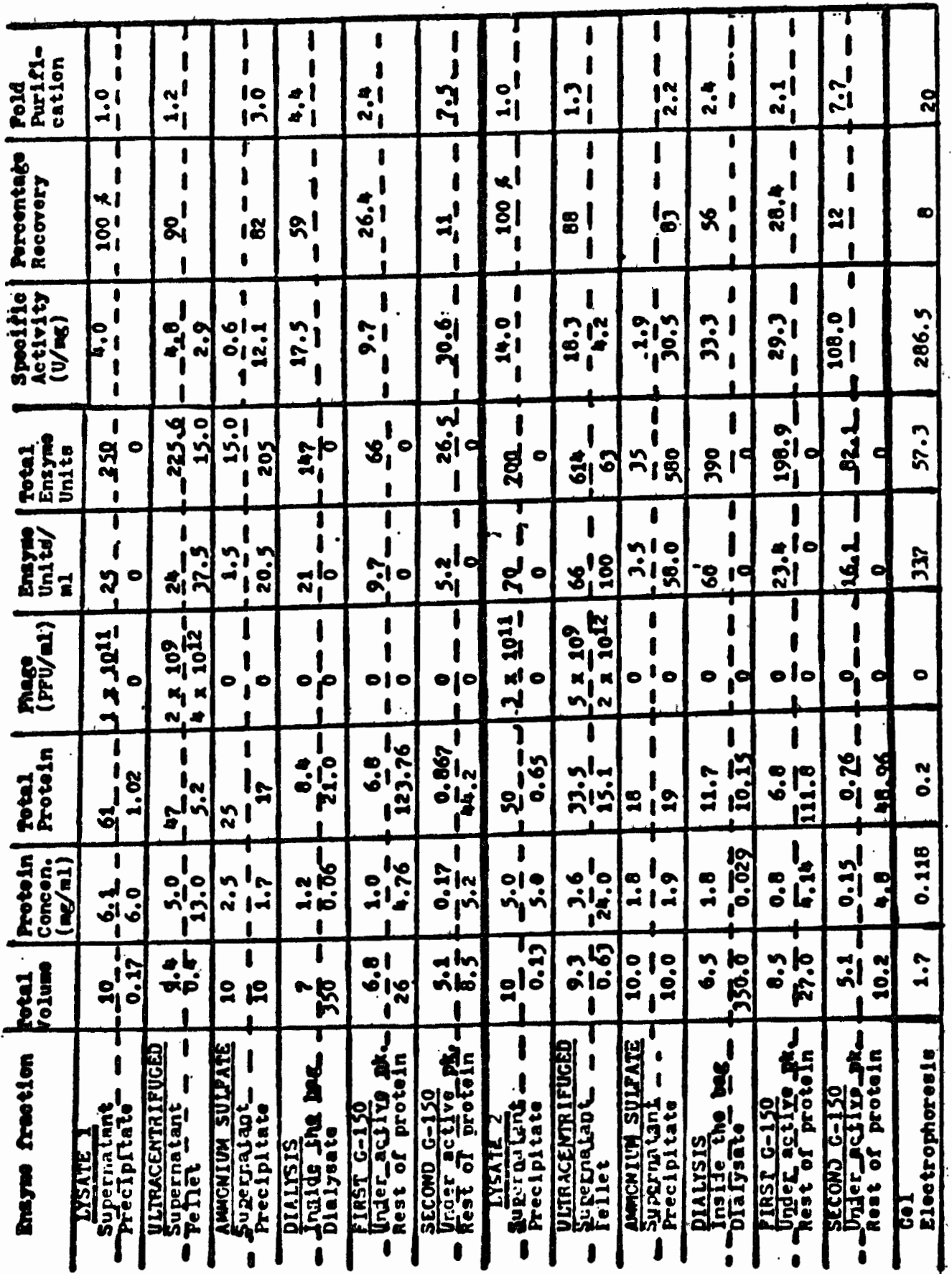


11. phage $7 \mathrm{v}$ lysozyme inactivation began at $40^{\circ} \mathrm{C}$, reached 50 per cent at $53^{\circ} \mathrm{C}$ and 100 per cent at temperatures of $75^{\circ} \mathrm{C}$ and higher.

PH Optimum. The purified enzyme was tested against various $\mathrm{pH}$ values to determine its $\mathrm{pH}$ optimum. The $\mathrm{pH}$ optimum was determined by observing at which $\mathrm{pH}$ the $7 \mathrm{v}$ lysozyme exhibited the greatest activity when all other conditions were held constant except the pH value. As seen in Figure 12, the pH optimum for phage $7 \mathrm{v}$ lysozyme activity was 7.0 .

\section{Molecular Weight Determination. The molecular} weight was determined using the gel filtration method described in Materials and Methods in which the elution rate of a protein from a Sephadex G-150 column is dependent upon the molecular weight. The results of the Sephadex gel filtration elution volume/void volume of each of the standard proteins are given in Table $\mathrm{V}$. These Ve/Vo were plotted against the log of the molecular weight of each of the standard proteins, and the result was a standard molecular weight curve. As seen in Figure 13, the standard curve is a straight line which shows that the rate of elution was directly porportional to the $\log$ of the molecular weight. The phage $7 \mathrm{v}$ lysozyme from the pooled active fractions of gel fractionation of Lysate 2 was put through the Sephadex G-150 column and the Ve/Vo was noted. The molecular weight of the unknown lysozyme was determined 


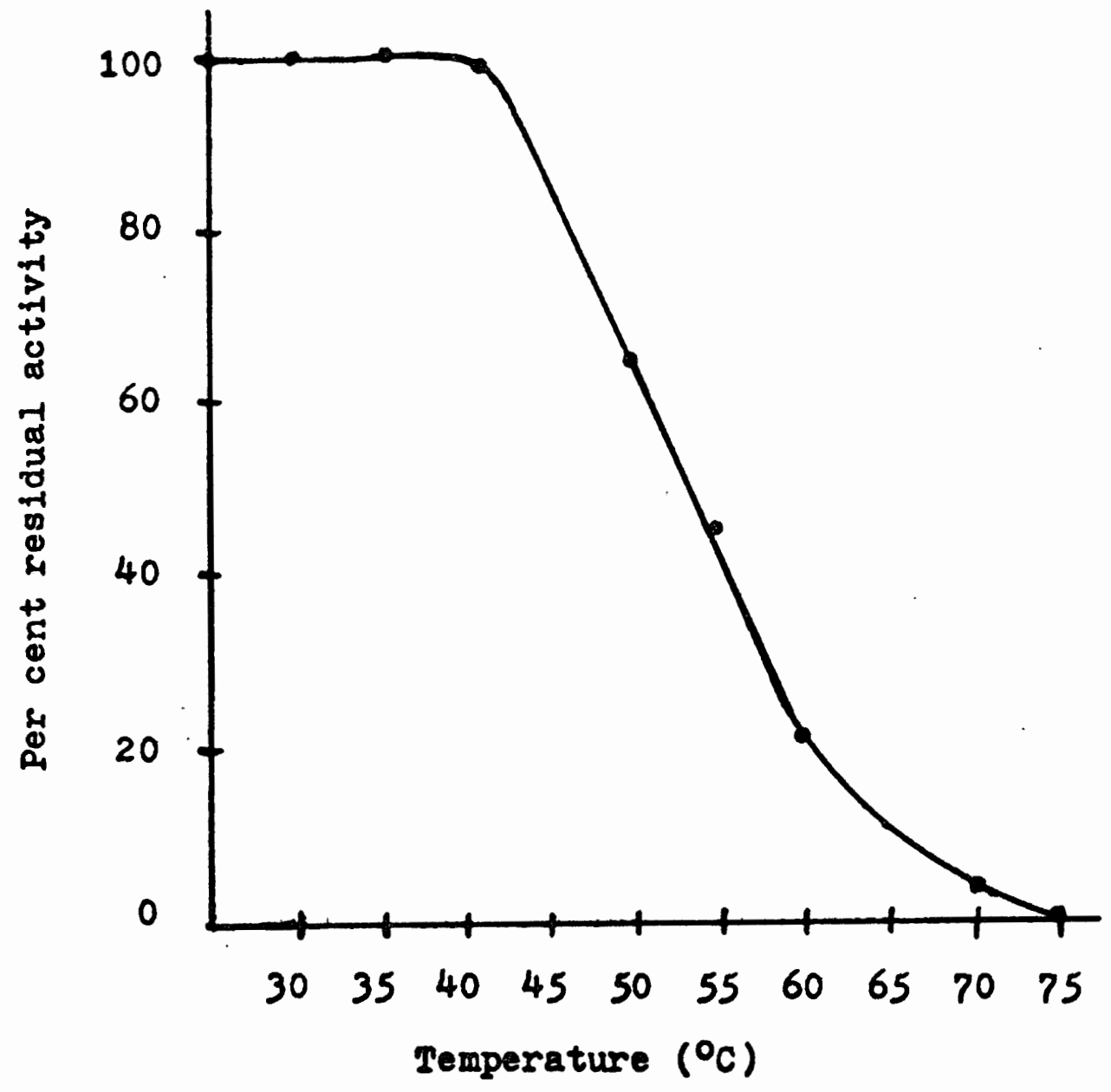

Pigure 11. Heat inactivation of the phage lyooryme. Per cent residual activity is the enzyme activity remaining after five minutes exposure to the different temperatures. 


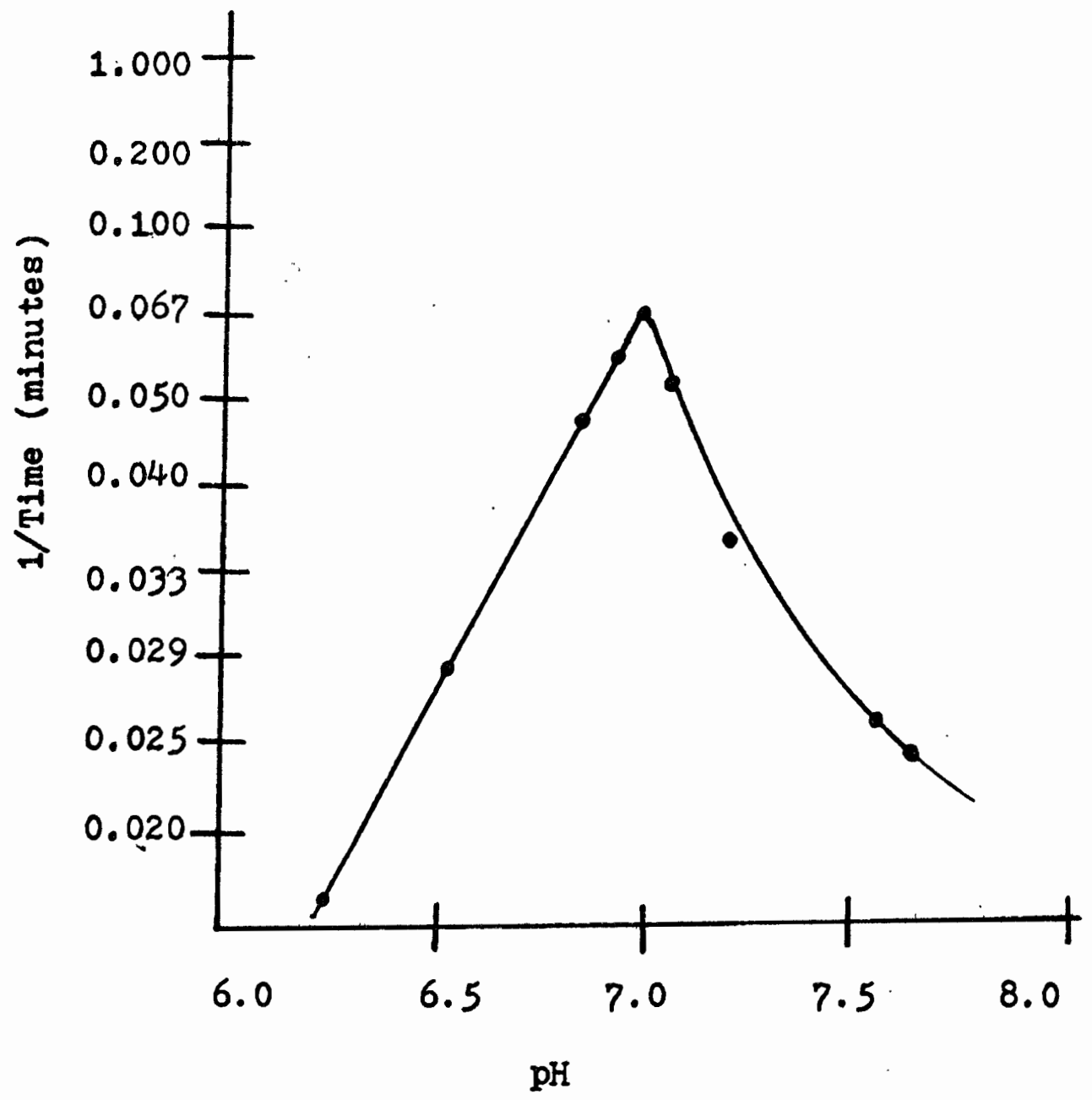

Figure 12. Enzyme activity versus $\mathrm{pH}$ in $0.1 \mathrm{M}$ phosphate buffers. 


\section{TABLE V}

\section{STANDARD PROTEIN VALUES FOR \\ MOLECU IAR WEIGHT \\ DETERMINATION}

\begin{tabular}{llll}
\multicolumn{1}{c}{ Protein } & $\mathrm{Ve} / \mathrm{Vo}^{\mathrm{a}}$ & $\mathrm{LOg} \mathrm{MW}^{\mathrm{b}}$ & $\mathrm{MW}$ \\
\hline Cytochrome c & 2.27 & 4.093 & 12,400 \\
Ribonuclease & 2.25 & 4.136 & 13,700 \\
Chymotrypsinogen A & 1.89 & 4.398 & 25,000 \\
Bovine Serum Albumin & 1.41 & 4.826 & 67.000 \\
Blue dextran 2000 & 1.00 & 4.155 & $2,000,000$ \\
\hline
\end{tabular}

asymbol for elution volume (Ve) over void volume (Vo). bymbol for molecular weight (MW). 


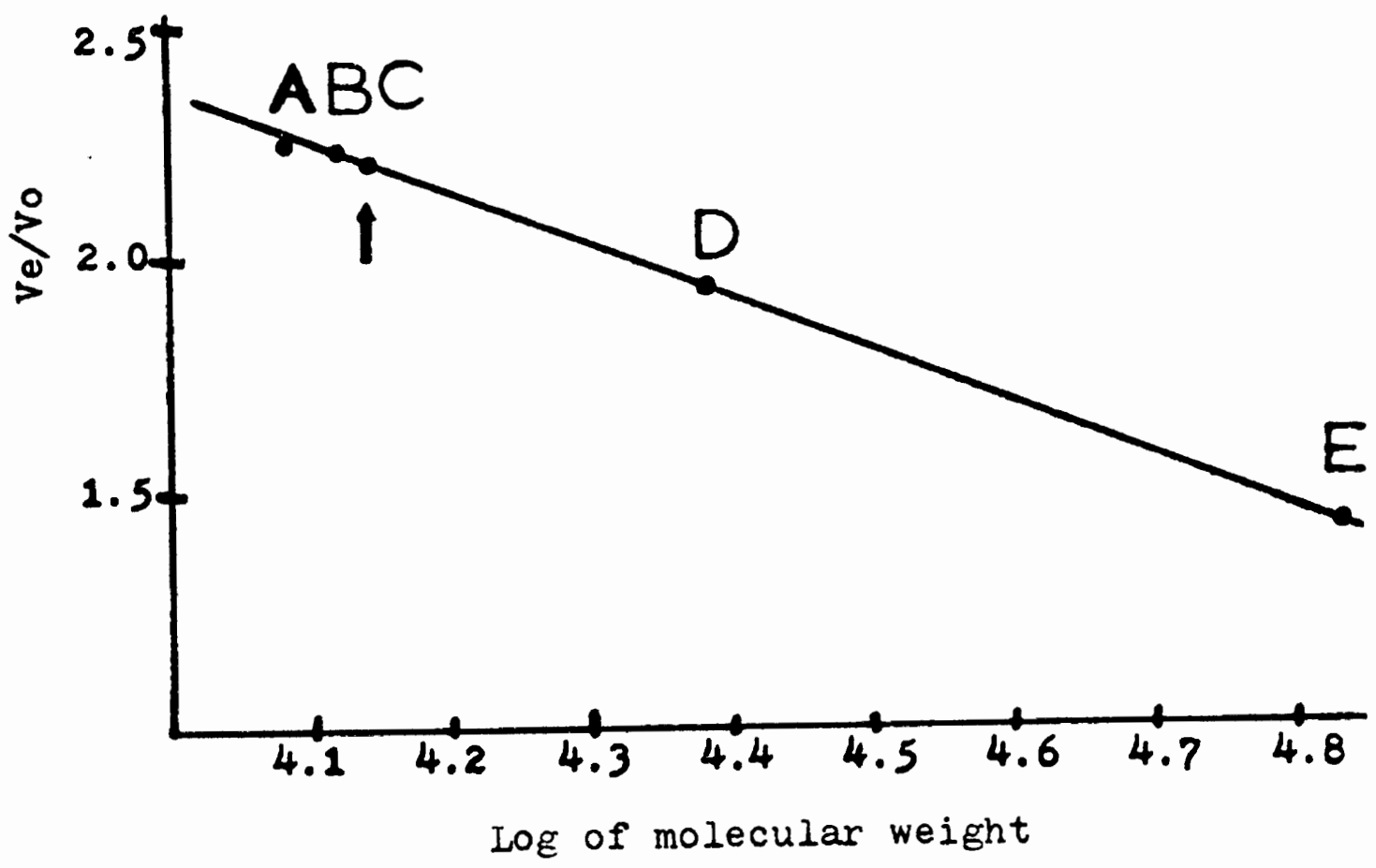

Figure 13. Standard molecular weight curve. $A$ is cytochrome $C, B$ is ribonuclease, $C$ is phage $7 v$ lysozyme, $D$ is chymotrypsinogen $A$, and $E$ is bovine serum albumin. Phage $7 \mathrm{v}$ Iysozyme is pointed out by an arrow. 
from the graph. The molecular weight of the phage $7 \mathrm{v}$ lysozyme was found to be 14,300 daltons.

Comparison of Enzyme Specificity. An experiment was carried out to determine if the phage $7 \mathrm{v}$ lysozyme and standard egg white Iysozyme (Sigma) had similar specificity for the same substrate. Dried $\underline{P}$. aeruginosa PS-7 substrate in $0.1 \mathrm{M}$ phosphate buffer, $\mathrm{pH} 7.0$, was added to each of two cuvettes. The experiment was begun by adding standard egg white lysozyme to each curette and lysis allowed to occur. After lysis, phage 7v lysozyme was added to one cuvette and standard egg white lysozyme was added to the other cuvette; and any further decrease in optical density, indicating further action on the substrate, was recorded.

As seen in Figure 14, the addition of standard egg white lysozyme or phage $7 v$ lysozyme had no effect on the rate of reaction. If the phage $7 \mathrm{v}$ enzyme acted on a different component of the bacterial cell wall, a decrease in optical density would have been expected. Since the phage $7 v$ lysozyme was active on the substrate only before, not after, incubation with standard egg white lysozyme, it was concluded that they might have similar specificities. This was not a definitive test for enzyme specificity, though, because optical density readings were influenced by the denatured proteins and debris in the solution. The extent that these proteins contributed toward the final 


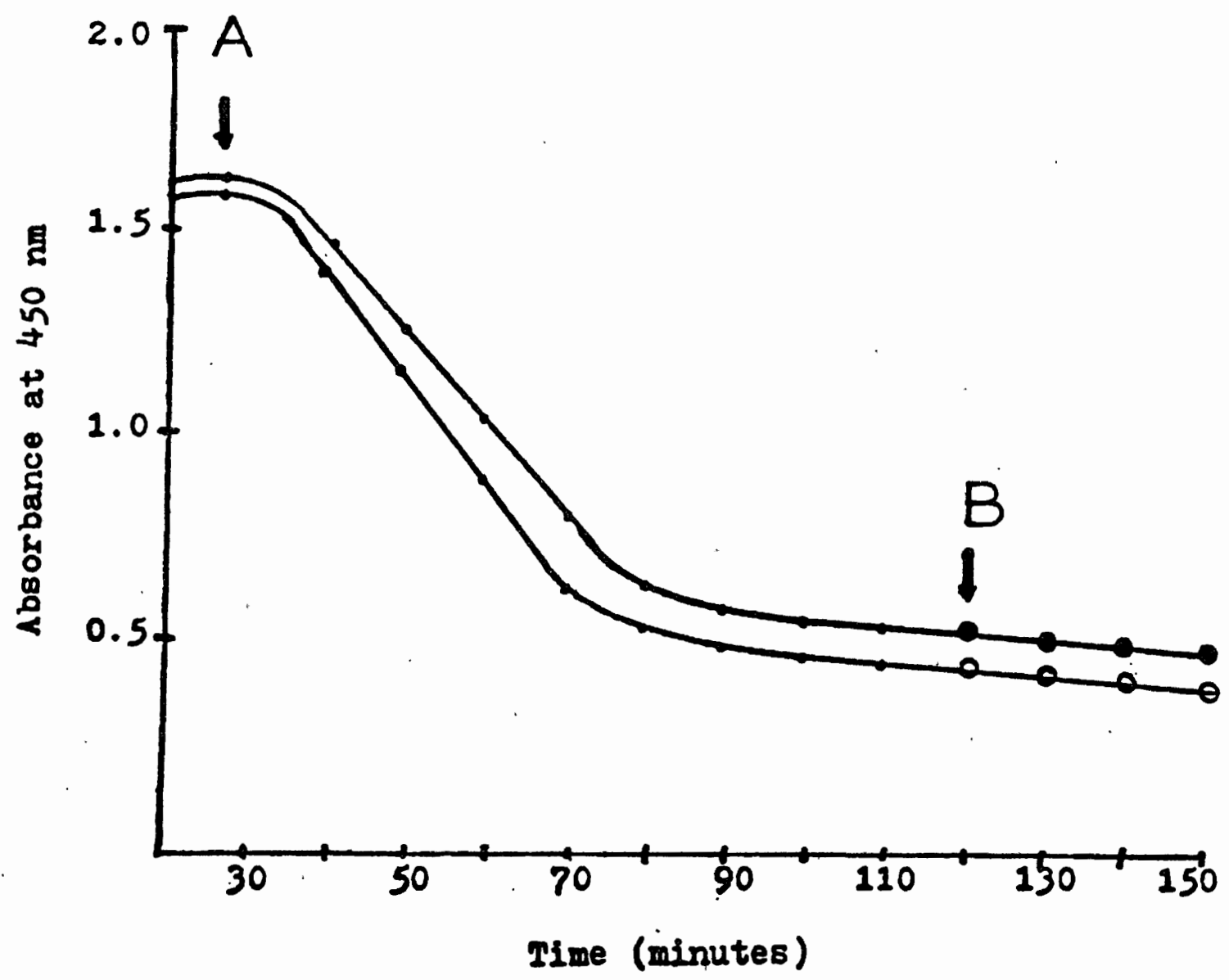

Figure 14. Action of egg white and phage lysozymes on the same substrate (P. eeruginosa cells).. $\Lambda$ is the time when 6 tandard egg white lysozyme was added and $B$ is the time when either standard egg white lysozyme (open circles) or $\mathrm{TV}$ phage lysozyme (closed circles) was added. 
optical density readings could not be determined. When the phage $7 \mathrm{v}$ enzyme or standard egg white lysozyme was added at the second time, there might have been more cell lysis, but the result could have been masked by the presence of proteins and debris released by the previous cell lysis.

Action on Other Bacteria. Iysozyme, in nature, has been found to be effective against different genera of bacteria (58). Using assay method 1, the partially purified phage $7 \mathrm{v}$ lysozyme was tested against other bacteria: As shown in Table VI, phage $7 \mathrm{v}$ lysozyme was found to be active against a wide variety of lyophilized Gram positive bacteria and acetone-dried Gram negative bacteria. Activity was calculated as a percentage of the activity obtained with $\underline{P}$. aemuginosa PS-7 as the substrate.

\section{Ability of Noninfectious Phage To Produce Lysozyme.} An experiment was carried out to determine if the presence of noninfectious phage would cause $\underline{P}$. aeruginosa PS-7 to produce lysozyme. P. aeruginosa PS-7 cells were mixed separately with $\mathrm{T} 1$ and $\mathrm{T} 7$ phages, which do not infect PS-7, using the method for preparing cell-free lysates. No lysozyme activity was detected in the cell-free supernatants by assay method 2. The presence of the infective phage $7 \mathrm{v}$ was necessary to produce lysozyme. 
TABLE VI

PHAGE 7V IYSOZYME ACTION AGAINST OTHER BACTERIA Bacteria Percentage Activity

Gram negative

Pseudomonas aeruginosa PS-7

$100 \%$

Pseudomonas aeruginosa 1c

$60 \%$

Pseudomonas denitrificans

$33 \%$

Escherichia coli DES

$30 \%$

Enterobacter aerogenes

$20 \%$

Alcaligenes faecalis

$17 \%$

Serratia marcescens

$9 \%$

Gram positive

Staphylococcus albus

$30 \%$

Micrococcus Iutea

$23 \%$

Bacillus subtilis

$20 \%$ 


\section{DISCUSSION AND COMPARISON}

WITH OTHER PAGE

IYSOZ YMES

Once a lytic effect was noticed on agar plates of Pseudomonas aeruginosa PS-7 and its bacteriophage 7v, a method of isolating and characterizing the lytic substance was needed. By examining procedures for purifying other lysozymes from bacteria other than . aeruginosa, a general outline of what was needed to be done was established. Various modifications upon these methods were used and a simpler method of purification was set up.

In order to detect lysozyme, a oensitive assay system was necessary. Two assay methods for lysozyme were found in the literature and compared. The most sensitive assay method had a choice of substrates: the standard substrate, Micrococcus Iysodeikticus, and a substrate made from Pseudomonas aeruginosa PS-7 ce118. The aubstrate made from P. aeruginosa, the natural host of the bacteriophage $7 \mathrm{v}$. was degraded more rapidly and therefore was used as the Bubstrate for assay method 2. The observation that the substrate made from the natiral host cell is the more Bensitive for phage enzyme detection was also poted for T2 phage by Trug1ta (57). 
result of phage $7 \mathrm{v}$ infection or if the lysozyme was an enzyme normally produced by $\underline{P}$. aeruginosa in the absence of phage infection. This was checked by assaying for enzymatic activity when $\underline{P}$. aeruginosa $\mathrm{PS}-7$ was grown in the absence of infective phage. The presence of bacteriophage was found to be necessary for $\underline{p}$. aeruginosa PS-? to produce lysozyme. Uninfected E. coli cells also lack lysozyme activity, and exhibit enzyme activity after infective phage was added (33).

P. aeruginosa was then grown separately with $\mathrm{T} 1$ phage and T7 phage to rule out the possibility that lysozyme could be produced by noninfective phages which could have a nonspecific interaction.with $\underline{P}$. aeruginosa PS-7. It was found that the phages could not induce Pseudomonas aeruginosa $\mathrm{PS}-7$ to produce lysozyme in the absence of infection. The presence of the specific infective phage, $7 \mathrm{v}$, was determined to be necessary to induce $\underline{P}$. aeruginosa PS-7 to produce lysozyme.

Lysates of $\underline{P}$. aeruginosa and phage $7 \mathrm{v}$ were made and centrifuged at low speed. The cells and cellular debris were spun out, but the lysozyme and the plaquexforming units remained in the supernatant. This result was also observed for E. coli and T4 (57). In order to further purify the lysozyme, the enzyme and the phage had to be separated. High speed centrifugation achieved separation of the lysozyme and the PFU. The lysozyme of E. coli was 
also observed to be separated from T2 PFU by high speed centrifugation (33).

After the lysozyme was separated from the whole viable bacterial cells and PFU, there still remained ample nonenzymatic proteins and materials with the lysozyme fraction. Ammonium sulfate precipitation was done to separate the lysozyme from these contaminants. A seventy per cent solution of ammonium sulfate brought down the most lysozyme and the least contaminants. At eighty per cent ammonium sulfate the recovery of the enzyme was reduced due to an inexplicable reason. Perhaps the high concentration of the salts involved inhibited lysozyme activity. Gel filtration was used to separate lysozyme from contaminating proteins. Different sizes of porous gel beads were used to try and hold back lysozyme while allowing larger proteins to escape from the column. A protein with a molecular weight of 10,000 daltons should have been held back by a Sephadex G-100 column. Phage 7v enzyme was not held up by Sephadex G-100, whereas the lysozyme was found to weigh 14,300 daltons. Molecular configuration may have been elongated, which would allow the lysozyme to slip past the porous beads, or the positive charge on the basic Iysozyme could have had some effect. In either case, a Sephadex G-150 column achieved better separation of the lysozyme and contaminants. The purification process can be followed by comparing 
specific activities, percentage recovery and fold purification. A dramatic rise in specific activity is seen after ammonium sulfate precipiatation with little loss of the enzyme sample. Nearly half of the enzyme is lost after dialysis, although the specific activity does increase. If the ammonium sulfate salts could be removed or inactivated by some other method which would conserve the enzyme sample, that would be helpful. Unfortunately, no other method could be found. Fewer dialysate changes might preserve some of the enzyme sample, but this would leave some ammonium sulfate salts in the enzyme sample.

Gel filtration resulted in approximately three fold purification and a dramatic rise in the specific activity as contaminants were separated from the lysozyme. The low enzyme recovery reflects the small sample size, three ml, used for the gel filtration process. Overall, the purification process resulted in a highly purified, but not definitely pure, lysozyme from crude lysates of Pseudomonas aeruginosa PS-7 and the bacteriophage $7 v$.

A drawback with this procedure is that the pure enzyme is in a fraction of protein which is closely associated with other non-lysozyme proteins. These contaminating proteins stay associated with the lysozyme throughout all the purification steps. In order to achieve a purification process that would enable a large amount of lysozyme to be accurately purified, these contaminating 
proteins would have to be eliminated. One method of purification that was not used in this.study was chromatographic separation by Amberlite columns as used by Tsugita with E. coli and T4 lysozyme (57) and Katz and Weidel with E. coli and T2 lysozyme (30). Chromatographic separation may not solve the problem of eliminating the lysozyme associated proteins because the contaminants were not evident in the studies of researchers working with $\underline{E}$. coli and its phage lysozymes. The non-lysozyme protein may have been ellminated by purification procedures used by E. coli researchers, and not by procedures used in this study; or, these contaminants are proteins present in Pseudomonas aeruginosa PS-7 or its phage $7 \mathrm{v}$ and not present in the E. coli systems.

A comparison of the lysozyme isolated from $\underline{P}$. aeruginosa PS-7 and phage $7 v$ was made against lysozymes isolated from other cell systems. As mentioned earlier, the $\underline{P}$. aeruginosa lysozyme and other lysozymes from E. coli and T2 and T4 phages were found in the same fractions of common purification steps $(33,57,58)$. Heat inactivation curves were similar when compared to the T4 lysozyme (58). Both $7 \mathrm{v}$ lysozyme and T2 lysozyme falled to act on a standard lysozyme substrate when the substrate was pre-incubated with egg white Iysozyme (33).

Lysozymes from cell-bacteriophage systems and lysozymes from sources other than bacteria or bacteriophages were 
compared to phage $7 \mathrm{v}$ lysozyme. The $\mathrm{pH}$ optimum of phage $7 \mathrm{v}$ lysozyme was 7.0, which falls in the scope of other $\mathrm{pH}$ optima of lysozymes from different sources. The $\mathrm{pH}$ optima can be seen in Table VI and they range from $\mathrm{pH} 3.5-$ 7.9. The molecular weight of phage $7 \mathrm{v}$ lysozyme was determined to be 14,300 daltons. This value is in the range of other molecular weights, as seen in Table VII. The range of molecular weights goes from 13,930 daltons for egg white lysozyme (32) to 24,000 daltons for papayalatex lysozyme (45).

Several avenues of research are suggested to further the understanding of phage lysozymes. A bacteriophage for a bacterium other than Escherichia coli has been found to produce lysozyme, so other bacteria and their phage could be checked for lysozyme activity. The amino acid sequence of this phage lysozyme could be determined and compared to other phage lysozymes to check the degree of similarity between lysozymes from different sources. Immunological studies could be used to determine the degree of similarity between lysozymes from different sources. Immunological studies could be used to determine the similarity with other phage lysozymes and also the time of lysozyme synthesis in the process of bacteriophage infection of the bacterial cell. Amino acid comparisons between the phage tail lysozyme and the lytic lysozyme could tell if the two lysozymes were identical. Once the bacteriophage- $\underline{p}$. aeruginosa system has been fuliy 


\section{TABLE VII}

PH OPTIMA FOR DIFFEREITT LYSOZYMSS

E. coli $\mathrm{T} 2$

6.5

Tsugita (54)

E. coli $\mathrm{T} 4$

7.3

Tsugita (54)

E. coli $\mathrm{T} 6 \mathrm{r}$

$7 \cdot 3$

Brown (7)

Goose Egg White

3.5

Ossermann (40)

Guinea Hen Egg

White

7.9

Ossermann (40) 


\section{TABLE VIII}

MOLECULAR IVEIGHT VALUES OF IYSOZYMUES

\begin{tabular}{|c|c|c|c|}
\hline Source & $\mathrm{MiW}^{2}$ & Reference & \\
\hline Esris-white & $\begin{array}{l}13,930 \\
14,000 \\
14,500 \pm 300 \\
14,600 \\
14.600 \pm 200 \\
17,000\end{array}$ & $\begin{array}{l}\text { Lehninger } \\
\text { Salton } \\
\text { Dubin } \\
\text { Phillips } \\
\text { Stecher } \\
\text { Miall }\end{array}$ & 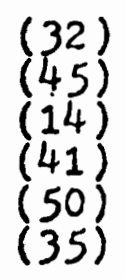 \\
\hline T2 Lysozyme & $\begin{array}{l}14,000 \\
15,200-21,000 \\
18,607\end{array}$ & $\begin{array}{l}\text { Katz } \\
\text { Katz } \\
\text { Inouye }\end{array}$ & $\begin{array}{l}(27) \\
(26) \\
(23)\end{array}$ \\
\hline T4 LJ'sozyme & 18,700 & Tsugita & $(54)$ \\
\hline Papaya-latex & 24.000 & Salton & $(45)$ \\
\hline
\end{tabular}

$a_{\text {jymbol for molecular weight (Mrii). }}$ 
investigated, a clinical application could be examined.

Pseudomonas aeruginosa has been found to be a

pathogenic bacterium which attacks patients whose immune systems are impaired in some way. $\underline{\text { P. aeruginosa infections }}$ are a very special problem because the bacteria are resistant to most of the common antibiotics (42). Externally applied lysozyme is not an effective killer of $\underline{p}$. aeruginosa, but when the lysozyme gene is carried in a bacteriophage particle, a major obstacle is overcome, namely the penetration of the protective lipopolysaccharide layers found in Gram negative bacteria. Access is gained to the bacterial cell interior through viral penetration. From that point, the viral infection can proceed until the bacterial cell is killed by cell lysis by phage lysozyme. Burn wounds have been observed to be infected with Pseudomonas aeruginosa by surface contamination. Antibotics taken internally do not reach the site of infection of tissue and blood vessel degradation in the site of the burn. The bacteriophage which has been observed to have the lysozyme gene might be sprayed topically on the burned surface to kill any contaminating $\underline{p}$. aeruginosa. Topical application of a phage would have the advantage of replication at the burn site and consequently the level of the killing agent would not decrease, but actually increase. Topical application of an antibotic would not have this advantage of replication at the burn site and would be 
diluted by body fluids and debris. Before this idea can be tried clinically, a burned animal model similar to the one described by stieritz (54) must be tried and the problems which might arise be overcome. A good review of burn wounds is found in Nathan (42) and that reference offers a good starting point for future research in burn wounds infected with $\underline{P}$. aeruginosa. When bacteriophages were first discovered, the idea that they might be used to combat bacterial infections was tried. Since researchers only tried this idea by injecting the virus or by ingesting the phage particle, and consequently antibodies or stomach acids destroyed the phage, this process was found not to work and further research along this line was abandoned. Since little or no antibody production is possible at the site of the burn wound because of massive tissue destruction. topical application of viral particles might be feasible in this case. More research needs to be done to test this hypothesis further before valid conclusions can be drawn. 


\section{CONCLUSIONS}

The production of lysozyme from Pseudomonas aeruginosa PS-7 cells was shown to be dependent upon the presence of the proper bacteriophage, 7v. Uninfected P. aeruginosa PS-7 cells did not show lysozyme activity. $\underline{\text { P. aeruginosa }}$ PS-7 cells mixed with noninfectious phages did not produce lysozyme. These results suggest the possibility that the lysozyme was synthesized in the host bacterial cell under the direction of a specific phage gene found in the $7 \mathrm{v}$ phage genome.

The enzyme was not an integral part of the phage particle, as evidenced by the separation of complete viable phage particles and the lysozyme using ultracentrifugation.

The phage enzyme was shown to be a Iysozyme on the basis of several criteria. The enzyme acted on the standard Iysozyme substrate (Micrococcus lysodeikticus cells). The enzyme was capable of lysing several bacteria under the proper conditions, as other lysozymes are able to do. The phage enzyme also shared common properties with other phage and non-phage lysozymes. The phage $7 \mathrm{v}$ lysozyme and egg white lysozyme were shown to have similar specificities on bacterial cell walls. 


\section{IITERATURE CITED}

1. Adams, M.H. Bacteriophages. Interscience Publishers, Inc. N.Y. 1959.

2. Andrews, P. "Estimation of the Molecular Weights of Proteins by Sephadex Gel-Filtration." Biochem. J. 21:222-223. 1964 .

3. Beck, O.E. and Gassen, H.G. "Translation of Bacteriophage T4 mRNA into Active Lysozyme by a Wheat Germ Cell-free System." Biochem. Biophys. Res. Commun. 74(1):16-24. 1977.

4. Bennett, J.V. "Nosocomical Infections Due to Pseudomonas." J. Infect. Dis. 130 (Supplement): S-4-S7. Nov. 1974.

5. Bergan, T. and Midtvedy, R. "Epidemiological Markers for PS. aeruginosa." Acta. Pathol. Microbiol. Scand. section B. 83:1-9. 1975.

6. Berger, L.R. and Weiser, R.S. Whe B-Glucosaminidase Activity of Egg White lysozyme." Biochim. Biophys. Acta. 26:571. 1957.

7. Brown. Arthur. "A study of lysis in Bacteriophageinfected E. col1." J. Bacteriol. 21,482490. 1956.

8. Brown, D.D. and Kozloff, L.M. "Morphological Iocalization of the Bacterlophage Tail Enzyme." J. Biol. Chem. 225:1-11.. 1957.

9. Campbell, D.H. Methods of Immunology. W.H. Benjamin Inc. N.Y. Pps. 45-48. 1970.

10. Chrambach, A., Reisfeld, R.A., Wycoff, M., And Saccari, $J$. "A procedure for Rapid and Sensitive Staining of Protein Fractioned by Polyacrylamide Gel Electrophoresis." Anal. Blochem. 20,150154. : 1967 .

11. Davis, B.J. "Disc Electrophoresis-II. Method and Application to Human Serum Proteins." Ann. N.Y. Acad. Sci. 121:404. 1964. 
12. DeMattini, M. Halegoua, S. and Inouye, M. "Iysozymes from Bacteriophages T3 and T5." J. Virol. 16(2):459-461. 1975 .

13. Determann, J. Gel Chromatography. Springer-Verlay. N.Y. Inc. Pps. 105-118. 1969.

14. Dubin, S.B. "Measurement of Translational and Rotational Diffusion Coefficients by Laser Iight Scattering." Methods of Enzymology. XXVI(Part C). Academic Press. N.Y. 1972.

15. Eichholtz, H., Freund-Molbert, E. and Stirm, S. "E. coli capsule Bacteriophages V. Lysozyme 29." J. Virol. 15(4):985-993. 1975 .

16. Elwell, M. and Schellman, J. "Phage T4 Iysozyme Physical Properties and Reversible Unfolding." Biochim. Biophys. Acta. 386:309-323. 1975.

17. Emrich, J. and Streisinger, G. "The Role of Phage Lysozyme in the Iife Cycle of Phage T4." virology. 26:387-391. 1968.

18. Fisher, E.F. and Allen, J.H. "Corneal Ulcers Produced by Cell-free Extracts of Ps. aeruginosa." Am.'s. Ophthalmol. 46(1) Part II:21-27. 1958.

19. Fishman, I.S. and Armstrong, D. "PS. aeruginosa bacteremia in Patients with Neoplastic Disease." Cancer. 20(3):764-773. 1972 .

20. Peary, T. "The Study of a Ps. aeruginosa Bacteriophage

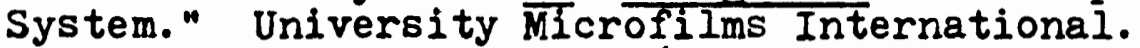
Michigan Ph.D. Thesis. 1963.

21. Fleming. A. "On the Antibacterial Power of Egg-White." The Lancet. 1:1303-1306. 1924.

22. Gabriel, 0. "Analytical Disc Gel Electrophoresis." Methods of Enzymology. XXII:565-584. Academic Press. N.Y. 1971.

23. Goodheart, C.R. An Introduction to Virology. H.B. Saunders Company. Phila. Pps. 121-123 and 135. 1969.

24. Gorenstein, D.G., Findlay, J.B., Luxon, B.A. and Kar, D. "Stereoelectronic Control in Carbon-Oxygen and Phosphorus-oxygen Bond Breaking Processes. $\mathrm{Ab}$ Initio Calculations and Speculations on the 
Hechanisms of Action of Ribonuclease A, Staph. Nuclease, and Lysozyme." Am. Chem. Soc. 29: 3473-3479. 1977 .

25. Green, A.A. and Jughes, W.I. "Protein Fractionation on the Basis of Solubility in Aqueous Solutions of Salts and Organic Solvents." Methods of Enzymology. Academic Press. N.Y. 1:75-78. 1955.

26. Inouye, M. and Tsugita, A. "Amino Acid Sequence of T2 Phage Iysozyme." J. Mol. Bio1. 27:213223. 1968 .

27. Jensen, K.B., Kleppe, G., Schindler, M. and Mirelman, D. "The Specificity Requirements of Bacteriophage T4 Iysozyme." Eur. J. Biochem. 66:319325. 1976.

28. Josslin, R. "The Iysis Mechanism of Phage T4: Mutants Affecting Iysis." Virology. 40:716-726. 1970.

29. Katz, V.W. and Weidel, W. "Reinigung und Charakterisierung des an T2-phagen gebundened Lysozyms." zeitschrift fur Naturforschung. 16b:363-368. 1961.

30. Katz, V.w. "Vergleichende Untersuchungen an teilchengebundenem und freiem T2-Lysorym und Dristallisierung beider Enzyme." Zeitschrift fur Naturforschung. 19b:129-133. 1964.

31. Koch, G. and Weidel, W. "Abspaltung Chemischer Komponenten der Coli-Hembran durch daran adsorbierte Phagen." Biochin. Biophys: Acta. 25(2):437. 1957.

32. Koch, G. and Jordan, E.M. "Killing of E. coli B by Phage-free T2 Lysates." Biochim. Biophys. Acta. 25(2),437. 1957.

33. Koch, G. and Dreyer, W.J. "Characterization of an Enzyme of Phage T2 as a Iysozyme." Virology. 6.291-293. 1958.

34. Ieach, A.A. and O'Shea, P.C. "The determination of Protein Molecular Weights of up to 225,000 by Gel-filtration on a 8 ingle column of Sephadex G-200 at $25^{\circ}$ and $40^{\circ} . " \mathrm{~J}$. Chromatogr. 17: .245-251. . 1965 . 
35. Lehninger, A. Biochemistry, Worth Publishers, Inc. New York. Page 57. 1971.

36. Lowry, O.H., Rosebrough, N.J., Farr, A.I., and Randall, R.J. "Protein Measurement with the Folin Phenol Reagent." J. Biol. Chem. 193:265275. 1951.

37. Mandelstam, J. and McQuillen, K. Biochemistry of Bacterial Growth. Blackwell Scientific Publications. Oxford. Page 79. 1968.

38. Miall, L.M. and Sharp, D.W.A. The New Dictionary of Chemistry. John Wiley and Sons, Inc. N.Y. Page 354. 1968.

39. Mir, M.A. "Lysozyme: a brief review." Postgrad. Med. J.. 53(619):257-259. May 1977.

40. Mirelman, D., Kleppe, G. and Jensen, H.R. "Studies on the specificity of action of bacteriophage T4 Lysozyme." Isr. J. Med. Sci. 11(11): 1174. Nov. 1975.

41. Mirelman, D., Kleppe, G. and Jensen, H.B. "Studies on the specificity of action of bacteriophage T4 Lysozyme." Eur. J. Biochem. 55:369373. 1975.

42. Nathan, P., Holder, I.A., MacMillan, B.G. "Burn Wounds: Microbiology, local host defenses, and current therapy." Chemical Rubber Company Critioal Review of Lab. Sciences. 4:61-100. 1973.

43. Osserman, E.F., Canfield, R.E., and Beychock, S. Lysozyme. Academic Press, N.Y. 1974.

44. Phillips, D.C. "The Hen Egg White Lysozyme Molecule." Proceedings National Academy of Science. 57:484. 1967.

45. Pruitt, B.A. "Infections caused by Ps. speejes in Patients with Burns and in other Surgical Patients." J.. Infect. Dis. 130(Supplement): S8-S13. 1974.

46. Reiland, J. "Gel Filtration." Methods in Enzymology. XXII: 287-321. Academic Press, N.Y. 1971. 
47. Rossmann, M.G. and Argos, P. "Exploring Structural Homology of Proteins." J. Mol. Biol. 105:7595. 1975.

48. Salton, M.R.J. "The lysis of Micro-organisms by Lysozyme and Related Enzymes." J. Gen. Microb101. 18:481-490. 1958 .

49. Schindler, M., Mirelman, D. and Sharon, N. "Action of Iysozymes from different sources on a

Soluble Iinear Peptidoglycan." IBr. J. Med. Sci. 11(11): 1174 . Nov. 1975 .

50. Schindler, M., Mirelman, D. and Sharon, N. "Substrate Induced Evolution of Lysozymes." Binchim. Biophys. Acta. 482:386-392. 1977.

51. Schnider, S.P. "The Biological Properties of PS. aeruginosa Bacteriophage $7 \mathrm{v} . "$ Master'B Thesis. Portland State University. 1969.

52. Silberstein, S, and Inouye, M. and Studier, F.W. "Studies on the Role of Bacteriophage T? Iysoryme during Phage Infection." J. Mol. Biol. 26: 1-11. 1975.

53. Stecher, P.G. et al. (Eds.) The Merck Index. Merck and Comp. . Inc. N.J. Page 633. 1968.

54. Stieritz, D.D. and Holder, I.A. "Experimental Studies of the Pathogenesis of Infections Due to $\mathrm{PB}$. aeruginosa description of a Burned Mouse mode1." J. Infect. Dis. 131(6):688691. 1975.

55. Stolp, H. "Bacteriolysis." Annu, Rev. Microbiol. 12:79-104. 1965.

56. Streisinger, G.. Mukai, F., Dreyer, W.J., Miller, B. and Horiuchi. S. "Mutations Affecting the Lysozyme of Phage T4." Cold Spring Harbor Symp. Quant. Biol. 26:25-30. 1961.

57. Trugita, 1 . and Inouye, $M$. "Purification of Bacteriophage T4 Lysozyme." J. Biol. Chem. 243(2):391-397. 1968.

58. Tsugita, A. "Phage Lysozyme and Other Lytic Enzymes." The Enzymes. Academic Press, N.Y. Y.343-382.

59. Weidel, W. and Primosigh, J. "Biochemical Parallels 
between Lysis by Virulent Phage and Iysis

by Penicillin." J. Gen. Microbiol. 18:513517. 1958.

60. Wharton, D.C. and MCCarty, R.E. Experiments and Methods in Biochemistry. The VacMillan Comp. N.Y. 1967.

61. White, T.J., Mross, G.A., Ossermann, E.F. and Wilson, A.C. "Primary Structure of Rat Lysozyme."

Biochemistry. 16(7):1430-1436. 1977 .

62. Williams, C.A. and Chase, M.W. (Eds.) Methods in Immunology and Immunochemistry. Academic Press, N.Y. 1:68-69. 1967.

63. Young, I.S. and Armstrong, D. "Human Immunity to Pseudomonas aeruginosa." J. Infect. Dis. 126(3):257-275. 1972.

64. Buchler Instruments, Inc. "Instructions for the Polyanalyst-An Analytical TemperatureRegulated Disc Electrophoresis Apparatus."

65. Worthington Enzyme Manual. Worthington Biochemical Corporation. N.J. Pps. 100-101. 1972. 


\section{APPENDIX I \\ COMPOSITION OF AITERNATIVE MEDIA}

Synthetic Minimal Medium ${ }^{2}$

$\begin{array}{lr}\mathrm{CaCl}_{2} & 15 \\ \mathrm{HeSO} & 120 \\ \left(\mathrm{NH}_{4}\right)_{2} \mathrm{SO}_{4} & 1,200 \\ \mathrm{Na}_{2} \mathrm{HPO}_{4} & 7.000 \\ \mathrm{NaH}_{2} \mathrm{PO}_{4} & 200 \\ \text { Glucose } & 10,000\end{array}$

aAll components are expressed as milligrams per liter.

Difco's Casamino Acid Medium

Total Nitrogen

Sodium Chloride

Ash

$\mathrm{P}$ as $\mathrm{PO} 4$

Iron, 3 grams Bacto-Casamino

Acids
10 per cent

14 per cent

20 per cent

2 per cent

15 micrograms 
APPENDIX II

SOURCE OF CHEMICAIS AND REAGENTS USED

Ammonium sulfate-Mallinckrodt Lot DMB

Ammonium Nitrate-Mallinckrodt Lot REK

Bovine Serum Albumin-Armour Labs Lot No. 111604

Chymotrypsinogen A-Pharmacia Fine Chemicals Kit No. 1CA

Coomassie Brilliant Blue R-250 Control No. 15306

Copper Sulfate-Miallinckrodt Lot RCS

Cytochrome c-Mann Research Lab Kit No. 20900-8109

Egg White Lysozyme-Sigma Chemical Comp. Lot No. I110B-078

Magnesium Sulfate-Mallinckrodt Lot TRK

Micrococcus lysodeikticus-Sigma Chem. Co. Lot No. 53B-1980

Nutrient Broth-Difco

Potassium Sodium Tartrate-Mallinckrodt Lot N. WRGV

Ribonuclease-Pharmacia Fine Chemicals Kit No. 1CA

Sephadex G-150 (10-40 mesh) Lot No. 288-1410

Yeast Extract-Difco 